\title{
Captured by Evil: The Idea of Corruption in Law
}

\author{
Laura S. Underkuffler ${ }^{1}$ \\ Mephistopheles: But tell me, Faustus, shall \\ I have thy soul? \\ "Doctor Faustus" \\ by Christopher Marlowe ${ }^{2}$
}

\section{INTRODUCTION}

"Corruption" is one of the most powerful words in the English language. Charges of corruption have condemned men, destroyed the lives of women, and accelerated the decline and fall of governments. Corruption is something that humans instinctively loathe, and that we try to excise from our midst. The word itself conjures something that is powerful, insidious, and destructive of human lives and institutions.

When it comes to the treatment of public corruption by law, corruption is a troubled concept. With increasing recognition of the costs of corruption for economic development, democratic

${ }^{1}$ Professor, Duke Law School.

Copyright Laura S. Underkuffler. This is a preliminary draft.

${ }^{2}$ Christopher Marlowe: The Complete Plays 280 (J.B. Steane ed. 1969). 
governance, international aid programs, and other world goals, attempts to articulate what this destructive force is have led to an avalanche of theoretical writing. In the last fifteen years corruption has been variously defined as the violation of law, a public servant's breach of a public duty, an agent's betrayal of a principal's interests, the pursuit of secrecy, the denial of equality in political influence, and other ways.

In the end, however, all of these efforts fall short. Corruption is more than law-breaking; it is more than breaching public duties. To say that "A is a thief" or that "A has breached his duty" is not to say that "A is corrupt." The latter is far more powerful, far more emotional, far more essential than the others. It is more than secrecy, or the denial of equal opportunity. It is a searing indictment, somehow, not only of A's act but of A's character. It is a statement not only of what A has done, but of what A has become.

In this work, I argue that corruption is a far more powerful idea than these existing traditional understandings have articulated: it is the idea of capture by evil, the possession of the individual by evil, in law. Just as we once believed in the "corruption of the blood" in American law, which decreed that the offspring of those who had committed crimes were believed to be irrevocably tainted by their parents' depravity, so we still retain - through the idea of corruption - the belief that individual evil extends beyond acts of wrongdoing, or the denial of equal opportunity, or the breach of the public trust.

It is this idea of corruption, I argue - the idea of "capture by evil" - that, although unarticulated, drives our understanding of corruption in law. It drives our understandings of corrupt judges, who, once corrupt, we believe will act so in every case. It drives our understanding of campaign finance reform, where we fear deep corruption of the process from the occurrence of corrupt acts. It drives our understanding of corruption as a systemic effect and systemic influence, 
which presents institutional dangers that are greater than other crimes, and that requires purgation rather than simple law enforcement.

This work explores this deeper understanding of corruption, its impacts in areas such as judicial corruption and campaign finance reform, and its implications for the principle of the rule of law.

\section{EXPLORING CORRUPTION: THE INADEQUACIES OF TRADITIONAL THEORIES}

Existing approaches to the idea of corruption fall into three broad categories: what I shall call "shell theories," "substantive theories," and "economic theories." Briefly, these can be described as follows:

- "Shell theories" define corruption on the basis of specific acts that are deemed to be wrongful on some other, unrelated normative basis (e.g., corruption "as a violation of law," "corruption as a violation of duty," and so on). They do not, themselves, engage in the explication or evaluation of these underlying normative theories.

- "Substantive theories" define corruption on the basis of particular, substantive evils that the theories, themselves, identify (e.g., corruption as "betrayal," "secrecy," "violation of the public interest," and so on). They make normative judgments - rooted in political or sociological theory - that "corruption," in their view, embodies.

- "Economic theories" are united in their view of corruption in economic terms. Generally, they combine shell theories (such as "corruption as illegality" or "corruption as breach of duty") with economic analysis which provides substantive, normative judgments about the positive or negative nature of corrupt acts. They range from theories that maintain that corruption is a certain kind of economic evil, to those that argue that corruption is an economic good.

Let us now consider these theories, and their relative success in capturing the essence of 
corruption, in more detail.

\section{A. Traditional Shell Theories}

Shell theories have become extremely prominent in academic treatments of the idea of corruption. The two most powerful theories of this type are "corruption as the violation of law" and "corruption as the breach of duty."

\section{(1) Corruption as violation of law}

As James C. Scott's classic work in the field begins, "[c]orruption, we would all agree, involves a deviation from certain standards of behavior. The first question which arises is, what criteria should we use to establish those standards?"3 If our concern is public corruption, perhaps the most obvious place to start is this: corruption involves the violation of law.

This understanding is based upon a common-sense observation. When we think of corruption by government actors, we tend to think of crimes: bribery, fraud, extortion, embezzlement, and kickbacks on public contracts, and so on. ${ }^{4}$ There seems to be a strong correlation between what we believe to be illegal acts and what we believe to be corrupt. Indeed, some observers would go further: if an official's act is prohibited by law, established by government, it is corrupt; if it is not so prohibited, it is not corrupt, even if it is otherwise undesirable. ${ }^{5}$

\footnotetext{
${ }^{3}$ James C. SCOtT, Comparative Political Corruption 3 (1972).
}

${ }^{4}$ See Robert KlitgaARd, CONTROlling CORRUPTIOn 3-4 (1988) (discussing illegal acts commonly believed to comprise corrupt behavior).

${ }^{5}$ See John Gardiner, Defining Corruption, in COPING WITH CORRUPTION IN A Borderless World: ProceEdings of the FifTH InTERNATIONAL ANTI-CORRUPTION CONFERENCE 21, 26 (Maurice Punch et. al. eds., 1993). See also Michael Johnston, Political Corruption And Public Policy in AMERica 8 (1982) ("Corruption is abuse of a public role for private benefit in such a way as to break the law (or other formal administrative regulations) ...."). 
"Corruption-as-illegality" is a shell theory of corruption. Theorists who use this approach simply borrow the normative judgments made by law to establish what is or is not corrupt conduct. ${ }^{6}$ For instance, in determining whether a payment to a public official is corrupt, the critical question under this approach is whether that payment is illegal (and, perhaps additionally, involves private gain or other described characteristics). ${ }^{7}$ Legal norms are not evaluated, or criticized; they are simply employed as the primary source for identifying what we believe to be corrupt acts.

The association of corruption with illegality has a tremendous advantage: it imports all of the safeguards that we associate with legal procedures and legal rules into our treatment of this phenomenon. For instance, by requiring that violation of the criminal law be proven, the idea of corruption as illegality ensures that corruption is pursued in accordance with the principles of notice, fair procedure, and other safeguards that are a part of the commitment to the rule of law.

How useful, however, is this theory in identifying the essence of corrupt behavior? When we examine the idea of corruption-as-illegality, we find serious problems. Consider, for instance, the following statements:

- A has broken the law.

and

- A is corrupt.

The meaning of these statements is clearly different. We do not consider burglars, bank robbers, perpetrators of assault, or even many white collar criminals (for instance, those who

\footnotetext{
${ }^{6}$ See, e.g., SCOTT, supra note 3, at 4 ("relying heavily on legal norms, in defining corruption, while it too has shortcomings, seems the most satisfactory alternative").

${ }^{7}$ Susan Rose-Ackerman, Corruption and Government: Causes, CONSEQuences, and Reform 9 ("Payments are corrupt if they are illegally made to public agents, with the goal of obtaining a benefit or avoiding a cost.").
} 
engaged in simple theft or tax evasion) to be "corrupt." Although "corrupt" acts may be a subset of "illegal" acts, the meaning of these two ideas is clearly not the same.

Indeed, the lack of congruence between "illegality" and "corruption" is evident even when we limit our consideration to illegal acts that are of a type that we generally assume to be within an imagined core of corrupt conduct. Consider, for instance, payments made to induce an abuse of power for the achievement of private ends. As Scott has observed, this would "include[] acts as diverse as a peasant's minute payment to a public hospital orderly to ensure his seeing a doctor and a large tax firm's generous bribe to a politician in return for his fiddling with the tax laws to its advantage. ${ }^{\prime 8}$ Although both acts might be equally illegal, and within our general understanding of the kinds of acts that corruption involves, we would hesitate to call them equally corrupt - if, indeed, the first is corrupt at all.

Thus, notions of illegality are far broader than notions of corruption. In addition, and at the other end of the spectrum, what is illegal may fail to capture what we (nevertheless) firmly believe to be corrupt conduct.

Consider, for instance, Scott's treatment of corruption and machine politics. At the outset, Scott states an intention to adhere to an understanding of corruption that is rooted in the breach of "formal" or legal norms. ${ }^{9}$ However, when later discussing "electoral corruption" and machine politics, Scott includes rewards such as "local development programs, pork-barrel legislation, loan programs, and legal patronage" within the "corrupt" ambit. ${ }^{10}$ He acknowledges that in most instances, these rewards are not illegal. Indeed, the goal of the political machine is to control the

\footnotetext{
${ }^{8}$ SCOTT, supra note 3 , at 5 .

${ }^{9}$ Id. at 4.

${ }^{10}$ Id. at 96.
} 
organs of government and to institutionalize the corruption it bestows. As the political machine matures, the inducements it offers are "more typically embodied in general legislation, whereas previously they had been particularistic and often outside the law." 11

Thus, even those theorists who strive to adhere to the idea of corruption-as-illegality find it very difficult to do so. When the actual configurations of public corruption are considered, there are, quite obviously, corrupt acts that the law (as presently constituted) does not reach. Indeed, if - as Scott assumes in this passage - corruption can capture the machinery of government, and can bend the products of government (the law) to its will, it is apparent that we cannot depend upon the "legal" or "illegal" nature of conduct to identify corrupt or non-corrupt acts. We cannot expect corrupt actors, who control the levers of legislative and executive power, to punish themselves. If corruption can infect the law, "corruption" and "legal status" cannot be the same.

There is, in short, no guarantee that the law will condemn all corrupt conduct. Nor is there any guarantee that the law will - as a fundamental matter - implement the values in which the common condemnation of corruption lies. ${ }^{12}$ Although we generally assume that the law implements broader ethical or moral notions, there is no necessary connection between legality and what other, broader ethical or moral notions prescribe - a connection which "corruption" seems to demand. Indeed, as we have seen, the law itself can originate in corrupt practices, making reliance on the law for the articulation of normative standards a flawed and hazardous enterprise. ${ }^{13}$

\footnotetext{
${ }^{11}$ Id. at 112 .

${ }^{12}$ Scott recognizes the potential divergence between what "legality" provides and what "corruption" means; his solution is an injunction that we "must avoid the a priori moral judgments that the term "corruption' popularly connotes." Id. at 6 . Such a restriction might be theoretically possible; however, it is so artificial as to be of little use, as his subsequent divergence from this injunction in his discussion of machine politics proves.

${ }^{13}$ See Mark Philp, Contextualizing Political Corruption, in POLITICAL CORRUPTION: CONCEPTS AND CONTEXTS 41, 46 (Arnold J. Heidenheimer \& Michael Johnston eds., 2002). The possible disjunction between the law and deeper moral notions in this context is discussed by John Gardiner. He writes: "In Nazi Germany during World War II, Jews were forbidden by law to emigrate. If a passport inspector took $1000 \mathrm{DM}$ from a Jewish family and approved its
} 
Put another way, although a judgment of illegality may be placed on what we believe to be corrupt conduct, it is not the illegality which makes the conduct corrupt. Rather, we have other, preexisting reasons for believing that particular conduct is corrupt - pre-existing reasons that the idea of illegality does not, itself, capture. The stamp of illegality - even criminal illegality - does not define the corrupt conduct; it is simply a societally determined consequence for engaging in the conduct that we believe to be corrupt, on independent grounds.

In summary, the idea of corruption-as-illegality "suffers from being simultaneously too narrow and too broad in scope; all illegal acts are not necessarily corrupt and all corrupt acts are not necessarily illegal." ${ }^{\prime 4}$ The unrelated normative bases that this shell theory borrows - that of illegal conduct - does not, of itself, identify the essential nature of the corrupt transaction. Clearly, some additional understanding is necessary to identify what corruption is.

(2) Corruption as the breach of duty

Perhaps the deeper understanding that we seek is the idea of the breach of duty by the corrupt actor. Through the idea of breach of duty, perhaps we can identify the particular character of public corruption that the simple idea of illegality cannot provide.

The breach-of-duty conception of corruption is extremely common in the legal academic and political science literature. Writers from across the ideological spectrum identify breach of duty as the essence of the corrupt act. Formulations include the "misuse of authority"; 15 the "lack of

departure, could he act be called 'corruption'?” Gardiner, supra note 5, at 27.

${ }^{14}$ John G. Peters \& Susan Welch, Political Corruption in America: A Search for Definitions and a Theory, 78 AMERICAN POLITICAL SCIENCE REVIEW 974, 974-75 (1978).

${ }^{15}$ See David H. Bayley, The Effects of Corruption in a Developing Nation, in POLITICAL CORRUPTION: REAdings In COMPARATIVE ANALYSIS 521, 522 (Arnold J. Heidenheimer ed., 1978). 
integrity in the discharge of public duties"; 16 deviation from the "accepted norms"17 or the "formal duties"18 of a public role; the "violation of socially accepted norms of duty and [social] welfare"; 19 "violat[ion of] responsibility toward ... [a] system of public or civic order"; ${ }^{20}$ and so on.

This is a shell theory of corruption; this theory does not of itself determine what the duties in question are, or whether they have been breached. The core, normative judgments that this theory recognizes are independently established by laws, regulations, personnel handbooks, customs, interpersonal understandings, ethical standards, or other sources.

There are, however, several implicit characteristics that a corrupt breach of duty is assumed to involve. First, it is assumed that this must be more than simple failure to act or negligent behavior. If a public official fails to process applications, fails to vote, or otherwise fails to execute his public functions, such failures are not, simply of themselves, "corrupt." Nor is simple misfeasance in office congruent with corruption. An office holder who makes errors in the execution of his duties is not, by virtue of that behavior alone, "corrupt." There must be more: there must be, at the least, intentional misconduct. As Robert Brooks has emphasized, "[corruption is intentional.... Failure to meet a recognised duty is not necessarily corrupt. The corrupt official must

\footnotetext{
${ }^{16}$ See Arnold J. Heidenheimer, The Context of Analysis, in id. at 3,4.

${ }^{17}$ See Samuel P. Huntington, Political Order in Changing Societies 59 (1968). See also Carl J. Friedrich, The PATHOlogy OF Politics: Violence, Betrayal, CORRUPTION, SECRECY, AND PROPAGANDA 127 (1972) ("Corruption is a kind of behavior which deviates from the norm actually prevalent or believed to be prevail in a given context, such as the political.").

${ }^{18}$ See J.S. Nye, Corruption and Political Development: A Cost-Benefit Analysis, in 61 AMERICAN POLITICAL SCIENCE REVIEW 417, 419 (1967).

${ }^{19}$ See Ibrahim F.I. Shihata, Corruption - A General Review with an Emphasis on the Role of the World Bank, in CORRUPTION: THE ENEMY WiTHIN 255, 258 (Barry Rider ed., 1997).

${ }^{20}$ Arnold A. Rogow \& H. D. Lasswell, The Definition of Corruption, in POLITICAL CORRUPTION: READINGS IN COMPARATIVE ANALYSIS, supra note 15, at 54, 54.
} 
know the better and choose the worse .... ."21

In addition, the breach of duty in question must be of a serious nature: trivial acts of misconduct, even if intentionally done, are not "corrupt." There is, as we noted above, a loathsome quality to corruption. The breach of duty must be one that arouses the strong societal condemnation which we intuitively feel to be a justified response to corrupt acts.

Finally, there is the additional requirement - expressed by many courts and commentators - that the breach of duty must involve self-dealing or personal gain, by the actor, at the public's expense. ${ }^{22}$ For instance, one commentator states that corruption "is a general term covering misuse of authority as a result of considerations of personal gain, which need not be monetary." ${ }^{23}$

Thus, under this theory, we have identified the following core of corrupt behavior: it is the breach of a duty owned to the public, of an intentional and serious nature, which involves - as the result of that breach - anticipated private gain. Have we, through this formulation, captured the essence of corruption?

There is no doubt - when we consider bribery, extortion, embezzlement, and other forms of public corruption - that intentional, serious breaches of duties by public officials, motivated by private gain, are involved. It is apparent that this pattern of conduct is clearly -- perhaps necessarily - involved in these examples of corruption. However, are these elements sufficient to capture its meaning?

Consider, for instance, the following examples of intentional, serious breaches of duty, which

\footnotetext{
${ }^{21}$ Robert C. Brooks, The Nature of Political Corruption, in POLITICAL CORRUPTION: READINGS IN COMPARATIVE ANALYSIS, supra note 15, at 56, 59.

${ }^{22}$ See, e.g., ROSE-ACKERMAN, supra note 7, at 14, 9 (corruption involves "self-seeking”, "personal enrichment and the provision of benefits to the corrupts"); GeORGE C.S. BENSON, STEVEN A. MAARANEN, \& AlAn HeSlOP, POLITICAL CORRUPTION IN AMERICA xiii (1978) ("Political corruption is a general term covering all illegal or unethical use of governmental authority as a result of considerations of personal or political gain.").

${ }^{23}$ Bayley, supra note 15 , at 521, 522 .
} 
involve the reaping of private gain:

- $\quad$ A driver stopped for speeding offers a police officer \$20 to avoid arrest.

- A government official expedites or prioritizes a friend's visa.

- In response to the administration's promise to delay implementation of new regulations, an industry trade group issues an endorsement of the President in his re-election campaign.

- A legislator, gratefully remembering a campaign contribution, listens with particular attention to that contributor's concerns.

- A city attorney conceals remodeling in his home from a tax assessor.

- $\quad$ The city treasurer exaggerates his medical condition, and remains on citypaid disability leave.

- $\quad$ A city employee calls in sick, and goes to a ball game.

All of these actions seem to fall within the ambit of the breach-of-duty theory, which includes the violation of legal, social, and organizational norms. Yet, our conclusion that all are "corrupt" is far less certain. ${ }^{24}$ In some cases, this uncertainty may be due to unresolved questions in our understandings of the duties involved - for instance, our notions of proper or improper rewards to political supporters and contributors are notoriously confused. ${ }^{25}$ In other cases, the

\footnotetext{
${ }^{24}$ See Michael Johnston, Right and Wrong in American Politics: Popular Conceptions of Corruption, in POLITICAL CORRUPTION: CONCEPTS AND CONTEXTS, supra note 13, at 173 (discussing survey results for many of these and other potentially "corrupt" acts).

${ }^{25}$ For instance, when the contributing parties are constituents, there are difficult questions surrounding when exchange of attention and favors is a corrupt exchange, and when it is simply the ordinary grist of politics. See Walter Lippmann, A Theory About Corruption, in POLITICAL CORRUPTION: READINGS IN COMPARATIVE ANALYSIS, supra note 15, at 294, 295 ("[T] $]$ he exchange of favors is the elemental and essential motive power which operates the semi-private machinery inside the political parties which in their turn operate the official machinery of government.”). Often, whether we view attempts to influence legislators as corrupt or non-corrupt will depend upon deeper notions of governance, i.e., whether we see legislators as simple implementers of constituents' desires or as trustees bound to exercise independent judgment for the benefit of a broader public good. See, e.g., Theodor Eschenburg, German Attempts at the Legal Definition of Parliamentary Corruption, in id. at 404, 407, and Daniel Lowenstein, Political Bribery and the Intermediate Theory of Politics, 32 U.C.L.A. L. REv. 784, 831-43 (1985) (discussing political theories - such as "mandate," "trusteeship," and "pluralist" - in the context of bribery and candidates for legislative office).
} 
problem seems to lie elsewhere. There is no doubt but that concealing information from a tax assessor, disability fraud, and cheating one's employer on sick days are clear violations of duties with serious economic consequences for the public fisc. However, these characteristics alone do not make these actions "corrupt." Whatever their wrongfulness, they do not seem to involve the kind of loathsome wrongfulness that we ordinarily associate with corrupt acts.

Indeed, the "wrongfulness" that the breach-of-duty theory involves may not - in its extreme form - involve ethical or moral wrongs at all. A breach of a "public duty" is a breach of established laws, regulations, or other rules of conduct established by those who wield the powers of government. Although one might wish to anchor these duties in broader notions of "right" or moral conduct, there is nothing in the idea of corruption as breach-of-duty that requires that linkage. As many writers have noted, such "moralistic notions" are, in fact, an additional gloss which the breachof-duty model does not, of itself, involve. ${ }^{26}$

The indiscriminate sweep of the breach-of-duty theory should not surprise us, since this is, after all, a shell theory of corruption - one that simply borrows its understanding of prohibited (corrupt) acts from other sources. As was true of corruption-as-illegality, examined above, this shell theory simply uses as its normative core those laws, regulations, organizational and social rules, and other standards independently adopted by government or other powerful elites. In some situations, the existing norms or duties prescribed by government or other power brokers might be congruent with the "good"; but in other situations, those norms or duties might be distinctly harmful to out-ofpower groups, general economic goals, or other important interests. Indeed, in some cases, the norms or duties that are transgressed might, from an ethical or moral point of view, be more worthy of

\footnotetext{
${ }^{26}$ See, e.g., Nye, supra note 18, at 417; Colin Leys, What Is the Problem about Corruption?, 3 Journal OF MODERN AFRICAN STUDIES 215, 215-17 (1965).
} 
condemnation than their breach.

Thus, the possibility of "good corruption" - i.e., the breach of duties which avoids harmful red tape, circumvents unjust rules, or avoids ethically or morally unjust actions - arises under the breach-of-duty theory. ${ }^{27}$ Indeed, such acts may be "good," in their effects, even if the actor involved pursues them for purely self-seeking ends.

Although one could certainly conceptualize corruption in this way - as an intentional, serious breach of duty, which may have (as its effects) the taking of the economic, political, or moral high ground - this is not, in common usage, what we understand the word to mean. It is not "corruption" in this sense that fuels popular outrage or undermines regimes. By "corruption," we mean - as we previously stated - something that is powerful, insidious, and destructive of human lives and institutions.

In short, the idea of corruption as the intentional and serious breach of duty by a public servant seems to describe what many corrupt acts involve, but it is not enough alone. The idea of breach of public duty is both more and less than the core concept. It is more, in that it includes behavior that we do not, in fact, believe to be corrupt. It is less, in that it fails to capture the moral opprobrium or loathsomeness that we believe corruption to involve.

\section{B. Traditional Substantive Theories}

The failure of shell theories to capture the idea of corruption suggests that we need something more - something substantive - to capture the essence of corruption. Consider, for instance, traditional "substantive theories" which are commonly used (alone, or in combination with

\footnotetext{
${ }^{27}$ See, e.g., Jose Veloso Abueva, The Contributions of Nepotism, Spoils, and Graft to Political Development, in Political CorRuption: ReAdings in COMPARATIVE ANALYsis, supra note 15, at 534.
} 
shell theories) to define the corrupt act. These theories are more bold than shell theories, in that they directly address the normative questions that shell theories avoid. Substantive theories define corruption as involving particular, substantive evils - evils that these theories, themselves, identify.

(1) Corruption as betrayal and secrecy

The first and most common of the substantive theories is one that builds upon the breach-ofduty theory in the following way. Numerous commentators have observed that the breach-of-duty model, with (what we have called) its "shell" character, is inadequate alone to capture the essence of the corrupt act. In an effort to try to capture the particular, opprobrious nature of corruption, these commentators move to the idea of a betrayal of those whom an official serves. This is a substantive theory that uses the breach of a particular, substantive norm to identify the nature of the corrupt act. Under this theory, it is not enough that a public official (intentionally) acts in a way that is contrary to his sworn duty; this breach must be of a type that excites particular social condemnation. The public official must not simply disappoint us; he must betray us. $^{28}$

Under this theory, the breaches of duty that corruption involves are particularly condemnatory because of the position of trust that public officials necessarily enjoy. It is asserted that the existence of trust, and its betrayal, is the core of corrupt conduct. ${ }^{29}$ It is the particular nature of the trust relationship between the citizen and her legislator, or the citizen and her judge, which makes these relationships particularly crucial and which makes their betrayal particularly heinous.

\footnotetext{
${ }^{28}$ See, e.g., KLITGAARD, supra note 4 , at 24 (“corruption occurs when an agent betrays the principal's interests in pursuit of her own") (emphasis added).

${ }^{29}$ See, e.g., id. at 19 (corruption involves an agent who "betray[s] her role as a public servant for her own private gain or interests"); Philp, supra note 13, at 42 (in public corruption, the official "violat[es] ...the trust placed in him by the public"); Shihata, supra note 19, at 260 ("In all cases [of corruption], a position of trust is ... exploited to realize private gain.”).
} 
The legislator, or the judge, or the agency administrator, is not simply someone who is doing a job; he is someone who wields tremendous power, and who - therefore - stands in a special, almost fiduciary relationship to the members of the public whom he serves. As a result, his intentional violation of those sworn duties is particularly condemnatory; he has betrayed those whose relative weakness and trust he has exploited. ${ }^{30}$

The idea of betrayal of trust by public officials does seem to tap into the moral or emotional reservoir that corruption evokes. With the addition of this idea, have we succeeded in identifying the essence of the corrupt act?

First, it must be observed that corruption-as betrayal suffers, as a general matter, from the same inadequacies as the breach-of-duty theory upon which it is based. For instance, betrayal of trust - like breach of duty - is something that we would ordinarily assume to be morally condemnatory, but this is not necessarily so. Strictly speaking, one who betrays a trust is simply one who acts differently from the way that others had reason to expect. The "order" that the public duties and the instillation of trust were to uphold may be congruent with broader moral values, or they may not. We can imagine situations in which the betrayal of trust (in this sense) is morally condemnatory, and situations in which it is not. ${ }^{31}$ For the betrayal of trust to always be (by definition) of an opprobrious nature, we must elevate the idea of the honoring of trust itself to a morally iconic status - something that (in view of the fallibility of government) betrayal-of-trust theories are loathe to do.

\footnotetext{
${ }^{30}$ See, e.g., Syed Hussein Alatas, Corruption: Its NATURe, CAUSES AND FunCtiOns 2 ("[T] he essence of corruption ... can be described as stealing through deception in a situation which betrays a trust."). See also NiKLAS Luhmann, TRust AND POWER 4-17 (1979) and Carol Rose, Trust in the Mirror of Betrayal, 75 Boston U. L. ReV. 531, 557-558 (1995) (discussing the general importance of trust in personal and institutional relations).

${ }^{31}$ See FRIEDRICH, supra note 17, at 86, 109-112 (no positive changes could occur in a political system "if some men were not willing to betray the old order to the emergent one").
} 
Indeed, the problems that are involved in the use of simple betrayal-of-trust notions to identify corruption are easily illustrated. We (the public) are victimized by all breaches of duties by public officials, whether (for instance) the official leaves work early to play golf or expedites building permits for his friends. In both cases, the trust that we have placed in that official is betrayed. Yet we would most likely label the first "annoying" or "unethical," and only the latter "corrupt." There is something more to corruption than knowledge of our weakness or the betrayal of trust by those whom we empower. These elements are involved in corrupt conduct - but we reserve the "corrupt" judgment for only a subset of these acts. Corruption is, in short, a particular kind of breach of duty; it is a particular kind of betrayal of trust.

In an effort to capture this further, elusive character of corruption, some corruption-asbetrayal theorists have added the idea of treachery or secrecy as an integral part of the corrupt transaction. For instance, the sociologist H.A. Brasz has defined corruption as "the stealthy exercise of derived power" to the detriment of the public, "under the pretence of a legitimate exercise of that power." ${ }^{32}$ He explains:

Those who as subordinates, agents, and the like handle the affairs of principles are presumed to be and to act in good faith. If they sever the connection and enter into the service of a competitor or enemy of the principal they may, it is true, be branded as turncoats, but they are not guilty of corruption. [Corruption requires, in addition,] the treacherous venom of deceit, the pretence of being absolutely loyal to the principal whilst in actual fact being intent on benefitting onself and/or third parties.

The most essential characteristic of corruption is ... the furtive exercise of

\footnotetext{
${ }^{32}$ H.A. Brasz, The Sociology of Corruption, in Political CoRruption: ReAdings In COMPARATIVE ANALYsis, supra note 15 , at 41,42 (emphasis added).
} 
formal authority and power under the pretence of legality. ${ }^{33}$

Indeed, this element of secrecy seems to figure prominently in our images of corrupt acts. As one commentator has observed, the practical difference between campaign contributions and bribes may be that in the former, "parties openly espouse the ends which ... contributors hope to achieve as a result of their largesse." ${ }^{34}$ In one informal study, participants were confronted with a situation in which an industry announces that its most important goal is the defeat of a pending bill, and that it will support legislators if and only if they vote against it. When asked if this would be a bribe, many opined that it would not - presumably, at least in part, because of the seeming incongruity in finding corruption in open, above-board acts. ${ }^{35}$ Similarly, a public official who openly announces his intention to deviate from his sworn duties may be condemned as a renegade or lawbreaker - but it is unlikely that he will be called corrupt.

Thus, corruption and secrecy seem to be intuitively linked. However, upon deeper reflection, it is obvious that secrecy cannot be what identifies the corrupt act. On the one hand, an otherwise innocent transaction, done in secret for privacy or other reasons, is not transformed - by reason of its secrecy - into a "corrupt" one. Conversely, as Daniel Lowenstein has observed, "'[i]t would be anomalous [indeed] to conclude that an official with enough chutzpah to take bribes openly should thereby $[\mathrm{be}]$... exempt from prosecution." 36 A breach of duty or betrayal of trust, done in secret, is

${ }^{33}$ Id. at 42, 43 (emphasis added). See also ALATAS, supra note 30, at 3 (the essence of corruption is "stealing through deception in a situation which betrays a trust"); John Warburton, Corruption as a Social Process: From Dyads to Networks, in CORRUPTION AND ANTI-CORRUPTION 221, 224-25 (Peter Larmour \& Nick Wolanin eds., 2001) (describing the secrecy of corrupt transactions).

${ }^{34}$ Vladimer Orlando Key, JR., The TeChniques of Political Graft in the United States 387 n.1 (1936).

${ }^{35}$ See Lowenstein, supra note 25 , at 829-30.

${ }^{36}$ Id. at 830 . 
(perhaps) quite likely to be corrupt. But although that setting may increase the odds that we are looking at a corrupt transaction, it is not in the idea of secrecy that we locate its evil.

\section{(2) Corruption as inequality}

A more sophisticated take on the role of secrecy in public corruption is presented by theorists who see the problem of secrecy (and corruption generally) in democratic-governance terms. Under this substantive theory, it is not secrecy qua secrecy that is the problem with corrupt acts; it is that secrecy is incompatible with the way that we expect democratic government to be conducted. In this view, "[t]ransactions between citizens and politicians [for example] can be judged corrupt when they subvert or circumvent a democratic process and its associated values of openness, equality, equity and accountability." ${ }^{37}$ Secrecy, in this understanding, is important as an instrumental matter: it is important because it allows the subversion of the ideals of democratic governance, particularly, the equal treatment of all citizens.

The idea that inequality lies at the heart of corrupt public conduct has become increasingly prominent in recent years. ${ }^{38}$ Under this approach, a hallmark of a liberal democratic system is the idea that all citizens are equal before the law. Corruption - whether bribery, extortion, kickbacks on public contracts, nepotism, or other acts - quintessentially involves the denial of this principle. The unifying core of corrupt conduct is that some citizens are afforded special access, deals, processes, or contracts - or, in the case of extortion, the justice or other civil benefit guaranteed by

${ }^{37}$ Robert Williams, Corruption: New Concepts for Old?, in 20 THIRD WORLD QUARTERLY 503, 510 (1999).

${ }^{38}$ See, e.g., FRIEDRICH, supra note 17, at 31 (the idea of equality before the law "provides the setting for the modern and specific sense of corruption"); Denis Osborne, Corruption as Counter-culture: Attitudes to Bribery in Local and Global Society, in CORRUPTION: THE ENEMY WITHIN, supra note 19, at 9, 28 ("Bribes create inequalities. A corrupt system is unfair."); Shihata, supra note 19, at 260 (corruption involves the "grant[ing] [of] special favours [which] undermines the general obligation to apply public rules without discrimination"). 
law - for a price. Whether the corrupt act enables the citizen to obtain better than fair treatment, or simply fair treatment, the bottom line is that the principle of equality of all before the law has been deliberately violated. As Tina Rosenberg has described it, "[t]he doors of the bureaucracy close in the face of the poor; judges never rule against the wealthy and powerful; new entrepreneurs find it almost impossible to navigate huge bureaucracies and compete in a world of crony-dominated commerce." ${ }^{39}$

The observation that corrupt acts often involve a denial of equality seems to be a true one. Does this, however, successfully identify the core characteristic of corruption?

When we consider this question, several problems emerge. First, it is apparent that the idea of simple equality - or equal treatment of similarly situated persons - is inadequate, itself, to distinguish corrupt from non-corrupt decisions or acts. In the political sphere, for instance, similarly situated persons are often not treated equally, for reasons that we accept. We do not demand that a legislator weigh every constituent's interest equally, or that every hiring decision for public employment employ no discretionary elements. Although there are settings in which we maintain the ideal that all similarly situated individuals receive scrupulously equal treatment before the law (for instance, in the meting out of criminal punishments), in most areas of political or public life we are considerably more tolerant.

Indeed, these examples expose a fundamental question that haunts this theory: equality of what? When we speak of equal sentences for equal crimes, the idea of equality might be fairly straightforward. However, when we consider the more complex settings for corruption in government decisionmaking, the simplicity and clarity of this idea rapidly disintegrates. For instance, equality in the political process might mean:

\footnotetext{
${ }^{39}$ Tina Rosenberg, Latin America's Magical Liberalism, THE WILSON QUARTERLY, Autumn, 1992, at 62.
} 
- equal opportunity to make one's case at crucial times and places, ${ }^{40}$

- equal voice, in the sense of the ability to be heard or the ability to influence, in the making of public policy, ${ }^{41}$ or

- equal outcomes, in the sense of equal benefit from official policies.

Let us consider these possibilities. The first - equal opportunity to make one's case at crucial times and places - is the least demanding. Under this idea, a kind of "equal process" is required: citizens must be able to present their arguments, objections, and desires to government decisionmakers on equal terms. It draws heavily on the idea of corruption-as-secrecy: secret avenues and channels, available to some and not to others, are corrupt. The ability to petition government and to be heard must be freely, openly, and (thus) equally available to all.

Superficially, the idea of equal opportunity to make one's case seems unassailable. Indeed, we often enshrine this right, in the form of a guaranteed right to petition government, in constitutional or other foundational documents. ${ }^{42}$ However, our inquiry here is not about the robustness of this democratic idea, but whether it usefully distinguishes corrupt from non-corrupt conduct. When we consider this question, we find that the idea of equal opportunity falls far short. Despite the power of this ideal, we do not expect legislators, mayors, or other officials to spend equal time listening (in person) to each citizen or considering equally each citizen's written request. Nor do we expect all conversations that officials have with citizens to be public events, with open access to all. If an official has lunch with a particular constituent, or a private phone conversation with her, we might suspect that something corrupt is going on, but it is not the inequality in access

\footnotetext{
${ }^{40}$ See Robert S. Getz, Congressional Ethics: The Conflict of InTERESt ISSue 67 (1966).

${ }^{41}$ See, e.g., Edgar Lane, Group Politics and the Disclosure Idea, 17 WESTERn POLITICAL QUARTERLY 203, 205 (1964); Cass R. Sunstein, Political Equality and Unintended Consequences, 94 ColuM. L. Rev. 1390, 1392 (1994).

${ }^{42}$ See, e.g., U.S. CONST. amend. I.
} 
or the secrecy of the communication that is, itself, the corruption. It is, perhaps, a fertile setting for a corrupt act; but that corrupt act is something else.

The second possibility listed above - that of equal voice, in the sense of the ability to be heard or the ability to influence, in the making of public policy - is more demanding. Here we are saying that officials must not only afford citizens equal access - they must afford citizens equal influence. This principle would seem to underlie the common belief (for instance) that disproportionate influence of "special interests" is corrupt.

Although equal voice might be an ideal which is defensible in certain circumstances (for instance, "one man - one vote"), it is quickly apparent that this cannot be a general test for acceptable political decisionmaking or for distinguishing corrupt and non-corrupt conduct. For many reasons, citizens will have differing abilities to influence government policy - reasons that range from their personal stake in the matter, to the intelligence of their views, to the numbers of citizens who share their positions.

The final possibility above - that of equal outcomes, in the sense of equal benefits from political policies - is an even more extreme demand, and suffers from similar objections. The achievement of equal outcomes for all citizens as the result of government policies is not something that government can possibly guarantee. Nor is its absence a reliable test for the presence of corruption. Just as we would hesitate to label a politician's failure to give all constituents equal influence "a corrupt act," we would clearly not label a political process that produces unequal benefit "a corrupt public policy."43

What is missing in all of these equality theories is an underlying understanding of what

\footnotetext{
${ }^{43}$ See, e.g., Gardiner, supra note 5, at 28 (most would "probably feel uncomfortable using the term corruption in all situations where the political process produces policies which do not benefit everyone equally").
} 
democratic or representative government substantively guarantees. As Robert Williams has written, determining corrupt conduct "forces us to say something about the character of politics"- something about "our general sense of what is politically legitimate." ${ }^{44}$ Whether we view unequal opportunity, voice, or outcomes as corrupt or non-corrupt will depend upon complicated questions of political theory, such as whether we see legislators as simple implementers of constituents' desires or as trustees bound to exercise independent judgment for the broader public good. ${ }^{45}$ Corruption, under equality theories, is the subversion of the political process. We must know what the political process guarantees before we can begin to determine what corrupt acts are. The simple notion of equality does not answer such questions.

All of this is complicated by the fact that although we tend to endorse "equality" in the political process, we tolerate - indeed, celebrate - the existence of material inequality, which (in turn) exacerbates the political inequality which we condemn. Greater wealth means greater opportunities for financial support of candidates and causes, more social, political, and economic connections, and other ability to broker power in the halls of government - leading inevitably to inequality in opportunity, voice, and outcomes. If equality is our test, why is influence "corrupt," in one context, and acceptable in the other? Why is access to power obtained through wealth (payments to officials) "corrupt," and access to power obtained through wealth (economic or social influence) seen as the legitimate reward for economic success? Again, "equality" provides no answer.

Before we leave equality theories, one more argument in their favor must be considered.

\footnotetext{
${ }^{44}$ See Williams, supra note 37 , at 509 .

${ }^{45}$ See, e.g., Thomas Burke, Corruption Concepts and Federal Campaign Finance Law, in PoLiTICAL CORRUPTION: CONCEPTS AND CONTEXTS, supra note 13, at 645, 659 ("All standards of [political] corruption rest on some notion of what constitutes an ideal political community.").
} 
Although the idea of corruption-as-inequality might be hopelessly simplistic in policymaking contexts, perhaps it is more useful when simple, administrative acts by public officials are involved. If the official's duty is simply to administer or enforce an existing law, there is less room for deliberate, disparate treatment of similarly situated individuals. For instance, we might know, in the case of bureaucratic corruption, what the "rules" are and, as a consequence, when illegitimate, unequal treatment has certainly occurred. ${ }^{46}$ In other words, when the ideal of equality is considered, favoritism by the import-duties collector must be distinguished from favoritism by national legislators. ${ }^{47}$

Before we become too enthusiastic about this proposition, we must first acknowledge that the distinction between administering the law and creating the law is a notoriously difficult one. Arguably, few bureaucratic acts involve the mechanical application of the law to facts, with no discretionary or interpretive elements. Although not "lawmaking" in a formal sense, the argument for citizen "input" and influence in many bureaucratic decisions might be every bit as strong as in the traditional legislative arena.

Still, we can surely identify some acts, in the administrative arena, to which individuals are entitled on an equal basis. For instance, the processing of a foreign visitor's visa should not depend upon political influence or the payment of "speed money" to the consular official involved. Our instinctive outrage at such corruption of the administrative process is illustrated by the recent scandal involving David Blunkett, Britain's former top law enforcement officer. Blunkett resigned

\footnotetext{
${ }^{46}$ See Williams, supra note 37, at 508 (in the bureaucratic context, "rule following is anticipated"; bureaucratic organizations "characteristically operate on the basis of clear lines of authority and accountability", making it possible, in principle, to distinguish proper and improper actions).

${ }^{47}$ See, e.g., Arnold J. Heidenheimer, The Analysis of Electoral and Legislative Corruption, in POLITICAL CORRUPTION: READINGS IN COMPARATIVE ANALYSIS, supra note 15, at 361, 368.
} 
after acknowledging that his department had fast-tracked a residence visa for a Filipina nanny employed by his former lover, American magazine publisher Kimberly Clark. Although his personal role in the administrative action was unclear, Blunkett resigned, stating that "[a]ny perception of this application being speeded up requires me to take responsibility." 48

Press accounts of the affair were harsh. For example, one commentator wrote:

Until now, ... most people in this country ... believed the [visa] process was generally objective and fair. Now we know different. ...

$[T]$ his is, or rather was, the Home Secretary of a country which rightly prides itself on the low level of corruption in public life .... .

... Think ... of a Britain in which you had to place a pounds 20 note in your passport before negotiating the green channel at customs, a Britain in which your neighbor could buy passports ..., a Britain where every entitlement was actually a favour with a price. ${ }^{49}$

Thus, in the realm of visa processing, at least, the notion of equal treatment by government seems very straightforward. Consider, however, the following colloquy, as recently reported on National Public Radio:

Melissa Block, host: Heightened security since 2001 has made it harder for foreigners to visit the United States. Musicians are especially hard-hit because they have to get a new visa every time they tour the U.S. They say the visa bureaucracy has become burdensome and expensive. NPR's Martin Kaste reports from Rio de Janeiro.

Martin Kaste, reporting: Standing outside the Sao Palo Airport, Brazilian artistic manager Ana Buono is in a panic.

Bad weather has delayed the flight of her 68-year-old client, internationally known jazz musician Hermeto Pasqual. Now that he's finally here, they have

${ }^{48}$ James Blitz, Blow to Blair as Blunkett Goes, FinANCIAL Times (LONDON), Dec. 16, 2004, at 1.

${ }^{49}$ Mary Dejevsky, Don't Be Fooled: Blunkett is Guilty of a Serious Offence, THE InDEPENDENT (London), Dec. 22,2004 , at 25. 
to race to get to the US consulate in time for their visa appointment.

As their cab breaks multiple traffic laws, Buono and Pasqual go over the paperwork one last time. If he and the other band members miss their appointment, they'll also miss their concert date at Lincoln Center in three days. Ana says that the visas often come through at the last possible minute. Her booking agent in California, Bill Smith, says he can never be sure the visas will be ready in time for a concert ....... The [Department of Homeland Security] refuses to take phone calls about visa petitions, even from a desperate booking agent. Smith says when he has a big concert planned, the only way to get some peace of mind is to write a check.

Smith: You've got to use the defense mechanism of spending a thousand dollars to ensure that you'll get an answer within 15 days so that the tour can happen.

Kaste: The thousand dollars is the so-called premium processing fee which moves a visa into a special fast track. ...

Back in Brazil, manager Ana Buono says she found this shocking.

Buono (through translator): I said, "Wow, I thought it was just here in Brazil where you have to pay people under the table to get things done."50

The payment of "speed money" for the performance of bureaucratic tasks is as roundly condemned as corrupt in the United States as it is in Britain. No one in the United States would expect to slip a $\$ 100$ bill with court papers to be filed, or slip a $\$ 1,000$ check with visa papers to speed up their processing. Yet, in this case, preferential treatment for those who pay is not only tolerated, as non-corrupt - it is entrenched and formalized in law. The idea that unequal treatment of similarly situated individuals is the essential core of corruption is confounded by this case.

One could attempt to rationalize the situation by refining one's idea of equality; perhaps the operative idea is not equality of treatment (outcome) but rather equality of opportunity. Because the option to pay "speed money" is provided by law, the democratic principle of equal treatment by government is preserved: anyone who seeks special treatment, and is willing to pay for it, is entitled

\footnotetext{
${ }^{50}$ National Public Radio broadcast, December 7, 2004. Transcript available at http.//nl.newsbank.com/nlsearch/we/Archives (visited December 9, 2004).
} 
to it.

Is this the kind of "equality" that the theory of corruption-as-inequality envisions? Is the concern with "inequality," which corruption evokes, assuaged if there is equal opportunity to seek special favors, pay "speed money," and the like? It may be, if the special treatment is relatively easily obtainable by anyone - for instance, if anyone who asks is granted special dispensation, or if the amount of "speed money" required is small enough to be within the reach of just about anyone. However, if - instead - the published criteria for special favors specify personal (otherwise irrelevant) characteristics, or the amount of "speed money" (such as $\$ 1,000$ for an expedited visa) is clearly beyond a nominal gesture, it is difficult to see how equality, in any meaningful sense, is afforded. Indeed, if “equal opportunity" (regardless of individuals' available resources) is the criterion for non-corrupt conduct, there is no ground for condemning bribery, which is the most universally condemned corrupt act of all. As one commentator has written, "[i]n a strict sense, bribery is a quid-pro-quo on comparatively free and equal (if illicit) terms." ${ }^{\text {51 }}$ All individuals are (presumably) equally able to offer a bribe and obtain the benefits that the bribee has to offer. If denial of equal opportunity is the essence of corrupt conduct, there is no reason to indict the briberous system or the briberous act.

Thus, we are left in a conundrum. The idea of inequality seems to be associated clearly with the idea of corruption. It seems to be particularly important in the identification of the deficiencies in the governmental system - unequal treatment, access, influence - that corrupt acts by public servants so often involve. However, inequality - whether in opportunity, voice, or outcomes - does not accurately or unerringly identify corrupt conduct. We do not condemn, as corrupt, all unequal

\footnotetext{
${ }^{51}$ Michael Johnston, Measuring the New Corruption Rankings: Implications for Analysis and Reform, in POLITICAL CORRUPTION: CONCEPTS AND CONTEXTS, supra note 13, at 865, 875.
} 
opportunities to make one's case, or all unequal voice in the making of public policy, or all unequal outcomes in the sense of benefits from official policies. Nor do we applaud, as non-corrupt, all situations in which equal opportunity to obtain bureaucratic services or influence government decisionmaking is afforded. Although we might say that inequality is often the result of much of what we believe to be corrupt conduct, it is not the idea of inequality or equality, itself, that identifies the corrupt or non-corrupt core.

(3) Public interest theories

The problems with other substantive theories - particularly, the absence of adequate grappling with the normative ideas that associate betrayal, secrecy, or inequality with corruption have led some theorists to advocate an understanding of corruption that is both substantive and boldly normative. This approach "explicit[ly] and simply assert[s] that corruption involves the subversion of the public interest." ${ }^{, 52}$ The core notion here is that there is a public or citizenry which has distinct interests, and that those interests are damaged by private-regarding (corrupt) conduct. Self-seeking behavior, under this approach, may have personal or factional goals, ${ }^{.3}$ the important idea is that the public interest is sacrificed in favor of the personal interests of the corrupt actor or others of his choice.

Public interest theories of corruption are attractive. They seem to drive closer to the central

\footnotetext{
${ }^{52}$ Williams, supra note 37, at 505. See also Robert C. Brooks, Apologies for Political Corruption, in POLITICAL CORRUPTION: READINGS IN COMPARATIVE ANALYSIS, supra note 15, at 501, 507 ("The very essence of corruption is selfinterest regardless of public interest."); Carl J. Friedrich, Political Pathology, 37 POLITICAL QUARTERLY 70, 74 (1966) (corruption exists when a power-holder is induced by monetary or other rewards "to take actions which favour whoever provides the reward and thereby does damage to the public and its interests").

${ }^{53}$ See, e.g., Barry Hindress, Good Government and Corruption, in CORRUPTION AND ANTI-CORRUPTION, supra note 33, at 1,5 (a government that "pursues factional interests rather than the common interests of the community ... [is] corrupt.").
} 
issue: that corruption involves "bad conduct" in a deeply evaluative sense. However, do these theories truly serve this function?

Let us begin with the most obvious issue that public interest theories present. That is: what is the public interest? More particularly, "whose evaluation of the public interest is to be operationalized?" 54 There is no guarantee that members of a governing elite, let alone all government actors or all citizens, will share a particular view of the public interest in any given situation. Indeed, substantial arguments can be (and have been) made that the public interest may sometimes require practices that are generally believed to be corrupt. For instance, bribes and other pay-offs might be the justified means for assimilating new groups into the existing political system, ${ }^{55}$ or the way to circumvent bureaucracy in the service of economic entrepreneurs. ${ }^{56}$

The uncertainties involved in the articulation of the public interest lead us to another flaw in public-interest corruption theories. Our goal, through these theories, is to identify the deeper, normative ideal that corruption intuitively transgresses, and that prior theories fail to identify. If the public interest is simply viewed as an interest, "develop[ed] pragmatically from the conflict among contending ... interests, ${ }^{, 57}$ then the public-interest theory has advanced us little. As so imagined, the public interest has no necessary grounding in or congruence with any moral notion. If, instead, we understand the "public interest" to be some kind of transcendent notion, ${ }^{58}$ then the problem of

\footnotetext{
${ }^{54}$ Heidenheimer, supra note 16 , at 6 .
}

${ }^{55}$ See Huntington, supra note 17 , at 61 .

${ }^{56}$ See, e.g., Bayley, supra note 15, at 528, 529; Nathaniel H. Leff, Economic Development through Bureaucratic Corruption, in Political Corruption: Readings in Comparative ANalysis, supra note 15, at 510, 516 ("entrepreneurs and corrupted officials ... [may] produc[e] a more effective [economic] policy than the government").

${ }^{57}$ Heidenheimer, supra note 47 , at 369.

${ }^{58}$ See, e.g., Frank J. Sorauf, The Conceptual Muddle, in Nomos V: The Public InTEREST 183, 184 (Carl J. Friedrich ed.,1962) (discussing whether the public interest is to be viewed "as an ethical imperative ..., some superior standard of rational and 'right' political wisdom, or the goals or consensus of a large portion of the electorate"). 
subjectivity is solved, but we are left with another. How are we to determine the "public interest" under this understanding? Is the payment of "speed money," or the circumvention of bureaucratic red tape, in the "public interest" in this sense? These theories themselves give no indication of what this idea of the public interest is, or from what it is derived. Without resort to other theories (of government, economics, morality, equality, and the like), we are left with little clue as to how to analyze such questions.

Finally, public-interest corruption theories suffer from the same problem as legally-based theories, trust-based theories, and the like: they capture more than corrupt conduct in some cases, and less than corrupt conduct in others. As James Scott has observed, "we can imagine many acts we would commonly call corrupt - e.g., placing destitute immigrants illegally on the city payroll that could be considered in the public interest, just as we can imagine acts against the public interest - e.g., the legislative creation of tax loopholes for the very rich - which, however much they smack

of favoritism, are not commonly seen as corrupt." ${ }^{59}$ Although - once again - violation of the public interest seems to be involved in corruption, it does not identify its core.

\section{Economic Theories}

In recent years, some commentators have turned to the use of economic theories as a way to understand corruption. Economic theories generally fall into two categories, as described below.

(1) Corruption as the rectification of market failure, or as the reallocation of undesirable power arrangements

${ }^{59}$ SCOTT, supra note 3 , at 3. 
Under one set of economic theories, "corrupt acts" are identified in explicitly value-neutral and market-oriented terms. Under this model, public and private (including "corrupt") interests are simply conflicting claims which are mediated through legal and nonlegal market mechanisms. When legal schemes fail to reflect market pressures and realities, non-legal ("corrupt") transactions serve to reestablish the appropriate market equilibrium. ${ }^{60}$

A classic example of this approach can be found in the work of Bruce Benson and John Baden. Governments, they argue, operate by assigning, reassigning, modifying, or attenuating property rights. ${ }^{61}$ When individuals are confronted by the property rights scheme that government has created, they can respond in one of four ways. They can "accept the given structure of rights as defined by the public sector and thereafter acquire and dispose of resources through voluntary transfers." ${ }^{\prime 2}$ They can lobby government "in an effort to influence ... [the alteration of] the rights." ${ }^{\prime 63}$ They can "resort to theft." ${ }^{64}$ Or they can "obtain[] a rights modification that, in a sense, combines theft and government influence: a rights modification can be purchased from a corrupt government official who is endowed with appropriate discretionary control." ${ }^{95}$

Thus corruption, under this model, is a kind of "underground" or "black" market which arises "when the institutional structure precludes private owners from allocating their resources in a competitive [way]. ${ }^{966}$ As Robert Tilman observes, modern bureaucracies often implement what

\footnotetext{
${ }^{60}$ See, e.g., Bruce L. Benson, A Note on Corruption by Public Officials: The Black Market for Property Rights, J. LiBeRTARIAN STUD. 305 (Summer 1981); Bruce L. Benson \& John Baden, The Political Economy of Governmental Corruption: The Logic of Underground Government, 14 J. OF LEGAL STUD. 391 (1985).

${ }^{61}$ See Benson \& Baden, supra note 60, at 392; Benson, supra note 60, at 306.

${ }^{62}$ Benson \& Baden, supra note 60 , at $392-93$.

${ }^{63}$ Id. at 393 .

${ }^{64} \mathrm{Id}$.

${ }^{65} \mathrm{Id}$.

${ }^{66}$ Id. at 391, 191.
} 
is, in effect, a form of the mandatory pricing model of market economics. ${ }^{67}$ When there is a serious disequilibrium between the supply (of bureaucratic goods) and demand, the centralized allocative mechanism, which is the ideal of modern bureaucracy, may break down. That breakdown is corruption. ${ }^{68}$

Interestingly, the shell theory of corruption-as-illegality is crucial here: the acts that are deemed to be "corrupt" under this model are those that are not permitted by the governing legal structure. ${ }^{69}$ However, illegality is given no operational or normative significance beyond that simple statement. There is nothing which makes the legally sanctioned system of rights superior, in any moral or normative sense, to any other. ${ }^{70}$ Corrupt acts, qua corrupt acts, are neither good nor bad; they are simply the manifestation of interests, which are equal - in any normative sense - to any other interests in the competitive sea. As National Leff (a famous proponent of this view) writes, "[c]orruption is an extra-legal institution used by individuals or groups to gain influence over the ... bureaucracy. As such, the existence of corruption per sé indicates only that these groups participate in the decision-making process to a greater extent than would otherwise be the case." 11 Indeed, it is because of the undesirability of the legally-sanctioned system - i.e., its inefficiency that a system of underground "rights modification" (corruption) has arisen. ${ }^{72}$

The fundamental theoretical contribution of this theory - that corruption may, in fact, have

\footnotetext{
${ }^{67}$ Robert O. Tilman, Black Market Bureaucracy, in Political Corruption: ReAdings in COMPARATive ANALYSIS, supra note 15, at 62, 62 .

${ }^{68} \mathrm{Id}$.

${ }^{69}$ See Benson \& Baden, supra note 60 , at 393-95.

${ }^{70}$ See id. at $392-93$.

${ }^{71}$ Leff, supra note 56 , at 510 .

${ }^{72}$ See Benson \& Baden, supra note 60, at 392-93. The observations of David Bayley are typical of this view. Although corruption has costs, "it is not necessarily antipathetic to the development of modern economic and social systems". "Governments have no monopoly upon correct solutions ...." "Corruption may serve as a means for impelling better choices, even in terms of government's expressed goals." Bayley, supra note 15, at 521, 528.
} 
positive economic, social, or political outcomes - was a revolutionary insight in its time, even if controversial and now largely discredited. ${ }^{73}$ For the purposes of our inquiry, however, this theory adds little. The idea of corruption expressed in this theory is simply a restatement of the idea of corruption-as-illegality or corruption-as-breach-of-duty, theories whose deficiencies were exposed above. The uniqueness of this theory lies not in its unique definition of corruption, but in its unique understandings of the consequences of the corrupt act. Indeed, this economic theory is - if anything - less congruent with the general understanding of corruption that we are exploring, since any notion of moral opprobrium (as the result of illegality or breach of duty) is, under these theories, disassociated with the corrupt act. As a matter of empirical fact, corruption might well be seen as simply "illegal” acts, which (positively) rectify market failure and otherwise circumvent undesirable laws. However, this model captures none of the essential moral outrage that we associate with corrupt acts.

(2) Normative economic theories

Other theorists employ economic ideas to develop distinctly normative understandings of corruption. Under these theories, the first step is the identification of corruption with rent seeking. For instance, Jacob van Klaveren writes:

[C]orruption means that a civil servant abuses his authority in order to obtain

\footnotetext{
${ }^{73}$ Most contemporary scholars agree that these theories seriously underestimate corruption's other costs particularly, the costs involved in damage to the accountability and transparency of government. See, e.g., Prouab Bardhan, Corruption and Development: A Review of the Issues, 35 J. OF ECON. LITERATURE 1320, 1327-30 (1997); Paolo Mauro, The Effects of Corruption on Growth and Public Expenditure, in POLITICAL CORRUPTION: CONCEPTS \& CONTEXTS, supra note 13, at 339; Paul D. Hutchcroft, The Politics of Privilege: Rents and Corruption in Asia, in id. at 489, 493-95; Jean-Francois Medard, Corruption in the Neo-Patrimonial States of Sub-Saharan Africa, in id. at 379, 44447.
} 
an extra income from the public. ... Thus we will conceive of corruption in terms of a civil servant who regards his office as a business, the income of which he will ... seek to maximize. The office then becomes a "maximizing unit." 74

Corruption, thus, is defined as personal rent-seeking by government officials in derogation of their duties to their principals (higher officials, the public) as established by law. ${ }^{75}$ Such theorists acknowledge that rent-seeking might be a positive or useful phenomenon in this context, since it may allow productive activities that existing laws or other pubic duties do not allow. ${ }^{76}$ However, these theories carry a distinctly normative imprint. From an economic point of view, rent-seeking or corruption inevitably "introduce[s] costs and distortions. ... [I]t encourages excessive public infrastructure investment ... [and] discourages legitimate business investment." ${ }^{\text {,7 }}$ It addition, these theorists accept the idea that the rule of law is, itself, of great societal value, and that the delegitimation of government rules that corruption involves carries its own overwhelming costs. ${ }^{78}$

Do these normative economic theories capture the essence of corruption, in a way that other theories miss? They definitely recognize the opprobrious or loathsome nature of corruption, as it is generally understood. This brings them closer to the corrupt idea in a way that (for instance) corruption-as rectification of market failure does not. However, in what is this idea of the

\footnotetext{
${ }^{74}$ Jacob van Klaveren, The Concept of Corruption, in POLITICAL CORRUPTION: A HANDBOOK 25, 25-26 (Arnold J. Heidenheimer et al. eds, 1989).

${ }^{75}$ See, e.g., Rose-AcKerman, supra note 7, at 2-5, 14; KlitgaARD, supra note 4, at 19-23; Michael BEENSTOCK, ECONOMICS OF CORRUPTION (1977).

${ }^{76}$ See, e.g., ROSE-ACKERMAN, supra note 7, at 2, 9 (distinguishing between productive and nonproductive rentseeking (or corrupt) activity). For instance, "[b]ribes [may] clear the market." "Bribes [may] act as incentive bonuses." "Bribes [may] lower costs.").

${ }^{77}$ Id. at 3. For instance, "[t]he official seeks to maximize his or her gains, not the optimal level of services. ... If several officials have authority over the allocation of scarce benefits, the problems can multiply as each tries to extract a share of the gain." Id. at 14.

${ }^{78}$ See id. at $22-23$.
} 
opprobrious or loathsome nature of corruption rooted? Do these theories successfully identify the nature of the corrupt core?

To the extent that these theories rely upon illegality, itself, as the idea of corruption, they add little that is new. When individuals disobey the law, there are clearly costs to those legal rules and to the government that implements them. We might even believe that disobedience is "bad," in a moral sense, if our moral scheme demands it. However, the "bad" that is associated with general law breaking is not at all necessarily congruent with the "bad" associated with corruption. As we established above, not all law breaking is corrupt, and not all corruption involves law breaking. Although the idea of costs to government veers more closely to interests that are the essence of corruption, ${ }^{79}$ it is not illegality that identifies the corrupt core.

Let us consider, in the alternative, the economic bases on which these theories rest. The idea that individuals pursue their own interests - that they are driven by the desire to maximize their own interests - obviously does not distinguish corrupt from non-corrupt behavior. Under normative economic theories, self-interest motivates all human behavior, corrupt and non-corrupt alike. Not all self-interested actions are "bad" or "inefficient," let alone corrupt. Rather, corrupt actions involve a failure to channel self-interest toward "appropriate" or "productive" ends. ${ }^{80}$

How, then, do we determine whether particular exercises of self-interest are appropriate or productive? Normative economic theorists suggest that it is the efficiency of those actions that is the crucial criterion. For instance, Susan Rose-Ackerman acknowledges that identifying corruption is difficult - "[o]ne person's bribe is another person's gift." ${ }^{\prime 1}$ Her aim is not to set a universal

\footnotetext{
${ }^{79}$ See Part IV, infra.

${ }^{80}$ ROSE-ACKERMAN, supra note 7, at 22.

${ }^{81}$ Id. at 5 .
} 
standard for where to draw the legal line between praiseworthy gifts and illegal and unethical bribes. ${ }^{82}$ However, she does aspire to identify - through the lens of economic efficiency - "the factors that should go into the choice." 83

The idea that the efficiency of corrupt acts should be considered in policymaking is an obviously useful one. However, is the efficiency or inefficiency of particular acts truly useful in identifying their corrupt or non-corrupt nature? After even cursory reflection, it is apparent that this idea falls short. Certainly all inefficient actions are not corrupt, as "corruption" is generally understood. Actions by government actors can be incompetent, wasteful, market-thwarting, or otherwise inefficient, and not be necessarily corrupt. By the same token, corrupt actions are not necessarily undertaken for financial gain, ${ }^{84}$ or necessarily inefficient. ${ }^{85}$ An official could break the law and grant a special favor to his brother, with 1) no economic payoff for that official and 2) the achievement of greater "efficiency" for other, specified government ends. In short, although financial distortions and inefficiency may characterize many corrupt acts, and although they may be reasons why we condemn corrupt acts, we cannot capture the root idea of corruption in purely economic terms.

For those economic theories that retain the idea of "corrupt" acts as a meaningful one, something is needed beyond the ideas of self-interest and efficiency, ideas with which economic analysis is generally concerned. Neither self-interest nor inefficiency engenders the outrage or

${ }^{82} \mathrm{Id}$.

${ }^{83} \mathrm{Id}$.

${ }^{84}$ See, e.g., Hindess, supra note 53, at 4 ( "non-economic corruption" includes situations in which "[a] government puts pressure on police and [the] judiciary to protects its friends and to friends and to penalise its opponents"; "[a] ruling party appoints judges ... and uses the courts to destroy the political opposition"; "[a] government uses its powers to discriminate systematically in favor of some sections of the population and against others"; and so on).

${ }^{85}$ See, e.g., ROSE-ACKERMAN, supra note 7, at 25 (acknowledging that individual bribes "sometimes not only benefit the payer and the recipient but also enhance overall efficiency or fairness."). 
destructive power that corruption charges involve. There must be some other normative ideal that corrupt, self-interested, inefficient actions violate (and that non-corrupt, self-interested, and inefficient actions do not). For some economic-corruption theorists, this normative baseline is provided by "illegality"; 86 for others, it is provided by "breach of duty." 87 However, in every case, "[t]o be able to point to those cases of interest/income maximizing which are also politically corrupt, one has to appeal to constructions of public office and the public-interest which draw on norms and values which are external to the market model." ${ }^{\prime 88}$

Economics is, in short, a powerful tool for the analysis of corruption. Economic theories are a way to explain the incidence and effects of corruption; but they do not -- of themselves -- provide any new or unique way to identify the corrupt act. To the extent that economic theories retain the idea of corruption as a distinct social, political, or moral phenomenon, they presume the existence of other, unrelated norms that corrupt acts transgress. As a result, economic theories - while interesting - do not get us closer to understanding what corruption, as an essential idea, is.

\section{Combination Theories}

We have found that none of the traditional understandings of corruption - whether shell theories, substantive theories, or economic theories - captures the idea of corruption as it is generally understood. Although violation of law, breach of duty, betrayal of trust, secrecy, inequality, and inefficiency are often characteristics of corrupt acts, none of these theories

\footnotetext{
${ }^{86} \mathrm{Id}$. at 9 (defining corruption as payments "illegally made to public agents with the goal of obtaining a benefit or avoiding a cost") (emphasis added).

${ }^{87}$ See KLITGAARD, supra note 4, at 24; Flavio M. Menezes, The Microeconomics of Corruption, in CORRUPTION AND ANTI-CORRUPTION, supra note 33, at 119, 119.

${ }^{88}$ Philp supra note 13 , at 50 .
} 
successfully distinguishes corrupt acts from non-corrupt ones. Many acts that involve violations of law, breaches of duty, betrayal, secrecy, inequality, or inefficiency are not, in fact, corrupt. And whichever theory we choose, we can think of corrupt acts that fail to have that characteristic.

Before we leave traditional theories, there is another possibility to be considered. Perhaps these theories would successfully capture the idea of corruption if they were considered in combination, rather than singly. For instance, Mark Philp has offered what might be called a “combination theory." He states:

We can recognise political corruption when:

1. a public official (A)

2. in violation of the trust placed in him by the public (B)

3. and in a manner which harms the public interest, knowingly engages in conduct which exploits the office for clear personal and private gain in a way which runs contrary to the accepted rules and standards for the conduct of public office within the political culture,

5. so as to benefit a third party (C) by providing $\mathrm{C}$ with access to a good or service $\mathrm{C}$ would not otherwise obtain. ${ }^{89}$

Another, more elaborate combination theory is offered by Syed Alatas. In his book, he argues that corruption has the following characteristics:

(a) a betrayal of trust;

(b) deception of a public body, private institution, or society at large;

(c) deliberate subordination of common interests to specific interests;

(d) secrecy of execution ...;

${ }^{89}$ Id. at 42 (emphases added). Philp specifies that "the core of [the] fourth condition is the intention to act for private gain (one is not less corrupt for being unsuccessful)." Id. at 42 n.1. 
(e) the involvement of more than one person or party;

(f) the presence of mutual obligations and benefits, in pecuniary or other form;

(g) the focusing of attention on those who want definite decisions and those who can influence them;

(h) the attempt to camouflage the corrupt act by some form of lawful justification; and

(i) the expression of contradictory dual functions by those committing the acts. ${ }^{90}$

These theories combine betrayal of trust, secrecy, subordination of the public interest, illegality, and breach of duty. All of these must be present before an act is "corrupt." Do these elements, in combination, successfully capture the idea of corruption?

When we consider the problem of the over-inclusivity of traditional theories, the layering of requirements in this way is helpful. We do not mean, by corruption, the violation of any law, or the breach of any duty, or the subversion of any public interest; we mean only those violations, breaches, or subversions that involve (for instance) secrecy, betrayal, and self-dealing. Since all of these characteristics are associated with corrupt conduct, requiring their simultaneous fulfillment will obviously, and helpfully, narrow the scope of acts within our net.

However, do such combination theories eliminate the problem? Although we have presumably reduced the number of acts identified by these overlapping requirements, we still lack a way to distinguish - within that universe - corrupt from non-corrupt conduct. For instance (to use Philp's theory) there are certainly fewer acts that violate the law or other public "rules and standards," harm the public interest, and involve a breach of trust, for personal gain, than that simply

\footnotetext{
${ }^{90}$ AlATAS, supra note 30, at 2 (emphases added). Alatas states that "[ $\left.\mathrm{t}\right]$ he last mentioned is important to distinguish corruption from other types of criminal behavior. For example, an official is bribed to issue a business license. He acts as the issuer (one capacity) and acquires the bribe (second and contradictory capacity). This characteristic distinguishes corruption from theft, burglary, and embezzlement." Id.
} 
have one of these characteristics alone. Yet, all acts that share these characteristics are not corrupt. To paraphrase a previous example, a healthy government employee could call in sick or feign disability, and thereby violate applicable rules and standards, harm the public interest, and breach the public trust, all for personal gain - but we would not, in the absence of other conduct, consider the action to be "corrupt."

We could add other elements to this combination theory to make it more robust: for instance, we could additionally require that the act involve secrecy, inequality (of some kind), and/or inefficiency. However, for all of those cases where these elements will help to narrow the field, and target (what we believe to be) corrupt acts, they will, in other cases, create problems of underinclusivity, by excluding acts (such as overt bribes, "equal" bribing opportunities, and "efficient" bribes) that we nonetheless believe to be corrupt.

The bottom line is this. Combination theories can be seen, in a sense, as kaleidoscope presentations of traditional theories: the elements can be combined and recombined in complex combinations that are far richer or more exacting than those elements alone. The fundamental problem, however, remains. Corruption is more than illegality, breach of duty, betrayal, secrecy, inequality, the subversion of the public interest, and inefficiency, whether these elements are considered alone or together. Traditional theories, whether shell or substantive, alone or in combination, fail to account for significant and substantial aspects of prevailing beliefs and intuitions about what the idea of corruption is. Put another way, although all of these theories identify elements that are often important characteristics of corrupt acts, they are not the essence of corruption - they are not, alone or in combination, what comprises the corrupt core.

More is needed to understand this powerful idea. It is to the identification of that "more" that we now turn. 


\section{THE IDEA OF CORRUPTION: TOWARD A DEEPER UNDERSTANDING}

In this Part, I shall argue that our operative understanding of corruption is, in fact, far deeper and more complex than traditional understandings of corruption acknowledge. Furthermore, it is this deeper and more complex idea of corruption that silently motivates and shapes our treatment of public corruption in law.

This more complex character of corruption can be established through a series of propositions. First:

- $\quad$ Corruption is an explicitly moral notion.

Traditional theories, whether shell theories or substantive theories, labor to avoid the obvious: that corruption is an explicitly moral notion which serves, in its general understanding, to condemn conduct on moral grounds. Looking for the essence of corruption in the violation of law, breach of duty, betrayal of trust, poor economic outcomes, and the like, will always feel viscerally unsatisfactory if, in the end, the explicitly moral core of corruption is not recognized. Corruption is not simply the breach of some politically chosen standard; it expresses the transgression of some deeply held and assertedly universal moral norm.

Take, for instance, the bribery of public officials. Bribery is universally condemned. "Not a country in the world ... does not treat bribery as criminal on its law books." ${ }^{91}$ No one admits to it; "[n]ot merely the criminal law - for the transaction could have happened long ago - but an innate fear of being considered disgusting restrains briber and bribee from parading their exchange." 92 The

\footnotetext{
${ }^{91}$ JOHN T. NOONAN, BRIBES 702 (1984).

${ }^{92}$ Id. at $702-03$.
} 
shame associated with bribery is so strong that it goes beyond the merely illegal. Rather, it points to the deeply moral nature of the crime. ${ }^{93}$ When Vice President Spiro T. Agnew resigned in 1973, he pleaded nolo contendre to tax evasion. "Agnew demonstrated that socially and politically, bribery was a far more damaging crime to be thought guilty of than tax evasion, felony though it was. As a tax evader he could try to hold his head up. As a bribetaker he was lost." ${ }^{" 94}$

The idea of bribery and other public corruption as morally depraved or "evil" has a long historical pedigree. ““ $[\mathrm{M}]$ oral opprobrium toward bribery is nothing new. It goes back some 4,000 years, with prohibitions found on Babylonian tablets."'95 The idea of political or public corruption as a deeply moral notion can be found in both Platonic and Aristotelian notions of democratic government, its maintenance, and its decline. ${ }^{96}$ Scholars of the mediaeval and early modern periods have found the fusion of ideas of corruption and evil throughout the writings of these periods in England and in France. ${ }^{97}$ In Le dictionnaire de l'Academie françoise, published in 1694, corruption is described as "concerning all moral deprivations and especially those with regard to justice .... ."98 In his famous dictionary penned in the eighteenth century, Samuel Johnson defined corruption as "[w]ickedness; perversion of principles." ${ }^{99}$ In this view, "[t]o say corruption is wrong is rather like

\footnotetext{
${ }^{93}$ Id. See also KLITGAARD, supra note 4, at 11.

${ }^{94}$ NOONAN, supra note 91 , at 582.

${ }^{95}$ Wilmer Parker III, Every Person Has a Price?, in CORRUPTION: The ENEMY WithIN, supra note 19, at 87

${ }^{96}$ See, e.g., FrIEDRICH, supra note 17, at 130-31; J. Peter Euben, Corruption, in POLITICAL INNOVATION AND Conceptual Change 220, 223042 (Terence Ball et al. eds., 1989).

${ }^{97}$ See, e.g. FRIEDRICH, supra note 17, at 127-41; Maryvonne Génaux, Early Modern Corruption in English and French Fields of Vision, in POLITICAL CORRUPTION: CONCEPTS \& CONTEXTS, supra note 13, at 107, 107-117.

${ }^{98}$ DiCTIONNAIRE DE L'ACADÉMIE FRANÇOISE DÉDIÉ AU ROI, (Genève, 1981), (reproduction of the $1^{\text {st }}$ ed., Paris, 1694), vol. 1 (s.v. corruption: "figurément, de toute dépravation dans les moeurs, et principalement de celles qui
} (quoting John T. Noonan). regardent la justice ...").

${ }^{99}$ [cite TK] 
saying that murder is wrong. Both statements express what is, in effect, a conceptual truth or grammatical necessity. $" 100$

The idea of political corruption as involving a raw, moral notion is acknowledged by some contemporary theorists. Arnold Heidenheimer observes that "[ $\mathrm{t}]$ he present usage of the term corruption in political contexts has obviously been colored by the meaning [of corruption] in the 'moral' category," namely, as involving “depravity," "moral deterioration," and "decay."101 Some analysts of political corruption embrace the idea of its moral content as an obvious truth. For instance, Wilmer Parker states that political corruption "is marked by immorality and perversion; [the corrupt person is] depraved; venal; dishonest." ${ }^{102}$ Robert Brooks describes political corruption as an "evil," corrupt transactions as "sins," and the engaging in corruption as the manifestation of "moral weakness." 103 In their book, Ronald Wraith and Edgar Simpkins state that "[c]orruption is above all a moral problem, immeasurable and imponderable."104

Indeed, the idea of corruption as a moral concept is so powerful that it seeps into the work of those who champion traditional theories, even as they take pains to exclude it from their definitions of the word. Although Robert Klitgaard describes his theory of corruption as a breachof-duty model, he acknowledges that "corrupt' invokes a range of images of evil ... . There is a moral tone to the word." 105 Colin Leys, who criticizes what he calls a "moralising approach" to corruption, ${ }^{106}$ nonetheless describes corruption in terms of the "strength of the rules of private

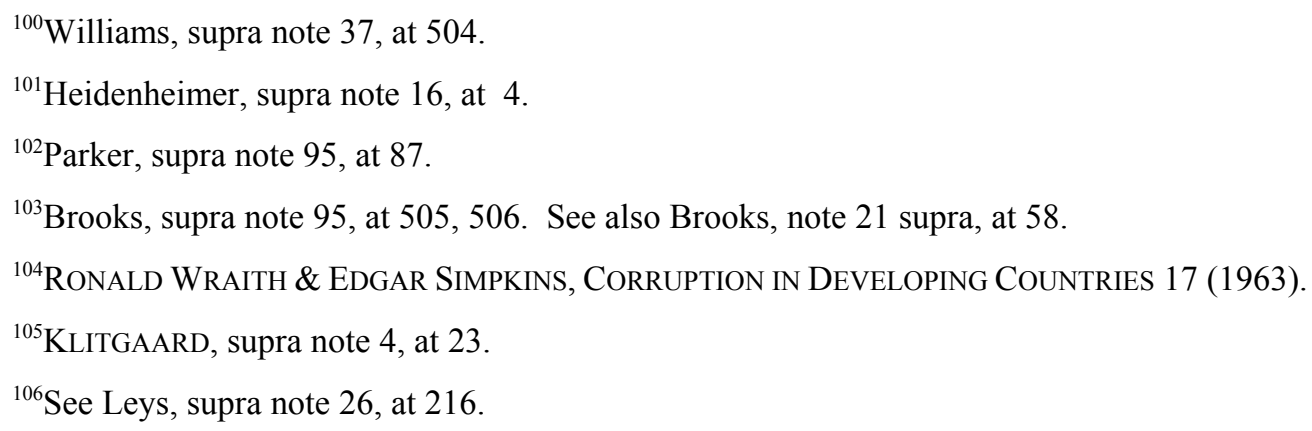


morality" and assaults on "moral rules."107 Bayless Manning, although not a "moralist" himself, acknowledges the explicitly moral nature of the idea of corruption as commonly understood. He states flatly that "the American looks upon his politics as a Morality Play," and "to his elected officials for moral affirmation[]."108 This "elevated moral vision of [the United States] and its officials," ${ }^{109}$ he argues, has driven Americans to continually expand the range of corrupt offenses to new (and, to his mind, unnecessary) lengths. ${ }^{110}$

What is this moral evil, that corruption represents? It is self-involvement, self-indulgence, the loosening and discard of the restraint of social bonds. It is, thus, associated with public and personal luxuriousness, indolence, excess, and decadence. ${ }^{111}$ For instance, Sayed Alatas describes the case of Gaius Verres (115-43 BC), a Roman ruler who was notable for the "rapaciousness and the extent of his corruption" - including "extortion, plunder, bribery, rape, sexual exploitation of other men's wives, treachery, murder, looting works of art, selling public offices, money-lending at usurious rates, [and] embezzling [from the estates] ... of the deceased."112 In Verres's case, the "lack of restraint" that characterizes the corrupt ruler "manifested itself in ... sexual relations, political intrigues, economic manipulations, and ... social behavior." ${ }^{113}$ Today's corruption, Alatas argues, is rooted in the same "materialism, impersonalism, status-seeking, greed for money and

\footnotetext{
${ }^{107}$ Colin Leys, New States and the Concept of Corruption, in Political Corruption: Readings in COMPARATIVE ANALYSIS, supra note 15 , at $341,341$.

${ }^{108}$ Bayless Manning, The Purity Potlatch: Conflict of Interests and Moral Escalation, in POLITICAL CORRUPTION: READINGS IN COMPARATIVE ANALYSIS, supra note 15, at 307, 307, 308.

${ }^{109}$ Id. at 308 .

${ }^{110}$ Id. at 308-312.

${ }^{111}$ See, e.g., Burke, supra note 45, at 646; Euben, supra note 96, at 222.

${ }^{112}$ AlATAS, supra note 30 , at 17.

${ }^{113}$ Id. at 29.
} 
power, and an unwillingness to adhere to moral values." ${ }^{114}$ Another contemporary writer observes that corruption involves "luxuriousness and indolence." 115 Yet another states that "whenever and wherever there is duty to be shirked or improperly performed ..., evil of this sort may enter in. This is the case within the church, the family, with educational associations, clubs, and so on throughout the whole list of social organizations ...."116

Indeed, contemporary associations of political corruption with general moral decadence and evil can be found in virtually any major city newspaper's account of a recent corruption scandal. Some colorful examples:

- $\quad$ The Vice-Mayor of Beijing, Wang Baosen, committed suicide in 1996 after having been presented with evidence implicating him and his staff in "systemic corruption." "Wang was guilty of squandering public funds, acquiring expensive real estate, and booking hotel suites for "pleasureseeking', according to officials. 'He was morally degenerate and lived a rotten life', the Xinhua news agency said." Of another implicated official, Chen Xitong, it is observed that he amassed a personal fortune, engaged in nepotism, and "kept a mistress for six years." 117

- In a story about a New York City detective convicted on corruption charges, it is noted that on one occasion, "one of his criminal friends orchestrated a bachelor party at a downtown hotel. The party became so raucous that everyone was thrown out, and the festivities resumed at a nearby brothel." 118

- In the fall of former Brazilian President Farnando Collor de Mello to corruption charges, it is noted that "proceeds from the influence-trafficking ring had been spent on building an elaborate garden at his ranch house ..., with eight artificial waterfalls and a swimming pool." He "drove around in a Mercedes convertible and maintained a luxury apartment in Paris, where

${ }^{114}$ Id. at 71 .

${ }^{115}$ Burke, supra note 45 , at 646 .

${ }^{116}$ Brooks, supra note 21 , at 58 .

${ }^{117}$ Stephen Hutcheon, Eighteen to Face Court Charges Over \$3 Billion Beijing Fraud, SyDNEY MorNING Herald, April 4, 1996, at 10.

${ }^{118}$ N. R. Kleinfield, Chinatown Officers Said to Forge A Partnership of Vice and Greed, N. Y. TIMEs, June 19, 1995 at A1. 
it was rumored that he would live in exile." In the end, his downfall was brought about by his brother, because he (Collor de Mello) "tried to seduce his [brother's] wife." 119

- In an article about rampant public corruption in India, a former Attorney General of the country is quoted as saying that "'[i]t's spread like a cancer."” "“It's reached a terminal state. There is a complete breakdown of [moral] values." The question, the story continued, is "whether the country's very soul has been irredeemably warped." 120

From these portrayals, it is apparent that corruption is not simply something that is undesirable or "bad" in an ordinary sense; rather, it is seen as a powerful, all-consuming evil, with what often appear to be religious roots. One contemporary analysis of political corruption discusses the "scarlet thread of bribery and corruption" their "jungle of nepotism and temptation." 121 Another informs us that the statement that "all power corrupts, and absolute power corrupts absolutely" has "a religious root, which is typically Western and Christian." It "harks back to the notion of the two kingdoms ..., the earthly and the heavenly city", and the susceptibility of humans to the power of moral depravity and moral decay. ${ }^{122}$ As one commentator breezily observes:

Corruption is something that we have all had to live with since Eve took the first bite of the serpents' apple, [and] ... that we will have to live with ... to the end of time. ... Lucifer, in his many names, was cast from the portals of heaven for the corruption that he bred, at least according to Milton [and others] ... . $[\mathrm{T}]$ he temptation to corrupt and to succumb is part of our estate ... . ${ }^{123}$

\footnotetext{
${ }^{119}$ Nathaniel C. Nash, Brazilian Leader Quits As His Trial Starts in Senate, N. Y. TimeS, Dec. 30, 1992, at A1.

${ }^{120}$ Edward A. Gargan, Corruption's Many Tentacles Are Choking India's Growth, N. Y. TIMES, Nov. 10, 1992,

${ }^{121}$ See WRAITH \& SimPKINS, supra note 104, at 12-13, 172.

${ }^{122}$ FRIEDRICH, supra note 17 , at 128.

${ }^{123}$ Barry A.K. Rider, Introduction, in CORRUPTION: The ENEMY Within, supra note 19, at 1, 1.
} at A1. 
In the same vein, a former prosecutor ends his commentary on a corrupt politician with a flourish: "every person will at some point in [his life] and at some level hear the seductive siren song of the corrupt temptress summoning us to, in Dante's words, enter ... the gates of Hell ... ."124

The idea of corruption as involving a temptation toward decadence to which an individual succumbs, and which - in turn - destroys that individual, ${ }^{125}$ has tremendous resonance in our understanding of this concept. Indeed, this brings us to our second proposition:

- $\quad$ Corruption is an external force, to which we, as human beings, are innately susceptible.

In contemporary treatments of the subject of corruption, even those who would resist the idea of corruption's religious roots often lapse into the same images of the corrupting process. In these characterizations, corruption is an external evil, which attacks and undermines better human impulses. It is, furthermore - because of our weakness - something to which we are all susceptible.

For some writers, this external force takes human form: the victim falls to the "corruptor"126 or "tempter" 127 whose influence he cannot resist. For instance, Joseph Borkin's study of corrupt judges ${ }^{128}$ is one of the most searing indictments of judicial corruption to be found. Yet, he is still

\footnotetext{
${ }^{124}$ Parker, supra note 95 , at 102-03.
}

${ }^{125}$ See, e.g., Euben, supra note 96, at 222-223.

${ }^{126}$ See, e.g., FRIEDRICH, supra note 17, at 138-39 (“The common understanding is that an official is corrupt when he accepts monetary or other reward ... for something he should or should not do anyway, or exercises the discretion entrusted to him so as to favor his corruptor.") (emphasis added); Susan Taylor, Taking the Profit Out of Corruption: A UK Perspective, in CORRUPTION: THE ENEMY WITHIN, supra note 19, at 1 ("[T] he corrupted obtains the benefit of the bribe, [and] the corruptor obtains a preference or advantage over the other. This advantage often leads to significant profit made by the corruptor ....") (emphasis added).

${ }^{127}$ See, e.g., H.A. Brasz, Administrative Corruption in Theory and Dutch Practice, in Political CORRuPTION: READINGS In COMPARATIVE ANALYSIS, supra note 15, at 243, 244; Rider, supra note 123, at 1.

\footnotetext{
${ }^{128}$ JoSEPh BORKIn, THE CORRUPt JUdGE: AN INQUiRY INTO BRIBERY AND OTHER High CRIMES AND MiSDEMEANORS IN THE FEDERAL COURTS (1962)
} 
hesitant to place complete responsibility for their acts on the corrupt judges themselves. "A judge," he writes, "cannot be corrupt alone. For every judge studied, there were the inevitable corruptors. They consisted most frequently of lawyers and clients, trustees and receivers, clerks and assistants, rapacious 'finders' and predatory 'intermediaries'." ${ }^{129}$ In this picture, the individual who pays the bribe is not simply a participant in the scheme; rather, he is a "corruptor" who induces the (passive) “corrupted" person's downfall.

Others describe the external, corrupting force in pathogenic terms. Corruption, in this view, "is not only the absence of an element or principle; it ... involve[s] the presence of some foreign element that debases or undermines the whole." ${ }^{, 130}$ Discussions of corruption are rife with images of corruption as a "virus," "131 "disease,"132 or "pathology." statement, a commentator opines that "[o]nce corruption finds its way into a certain place or sector, like a virus, it tends to spread out to other areas and sectors. ${ }^{" 135}$ The passage of the Foreign Corrupt

\footnotetext{
${ }^{129}$ Id. at 15 (emphasis added). Borkin notes, furthermore, that "[a]s a rule, the corruptors fared better than the corrupted judge in material reward." Id.

${ }^{130}$ Euben, supra note 96 , at 222.

${ }^{131}$ See, e.g., Yufan Hao and Michael Johnston, Corruption and the Future of Economic Reform in China, in POLITICAL CORRUPTION: CONCEPTS \& CONTEXTS, supra note 13, at 583, 584 ("Corruption 'is like a virus invading the body of the party and the state."”) (quoting former Chinese Communist party chief Jiang Zemin).

${ }^{132}$ See, e.g., Lippmann, supra note 25, at 296 (corruption is a "disease .. [of] the body politic"); FRIEDRICH, supra note , at 131-32 (same). Alatas describes public corruption as an "infection," an "infestation." See ALATAS, supra note 30 , at 5,72 .

${ }^{133}$ See, e.g., FRIEDRICH, supra note 17, at 135 (corruption is a "particular form of political pathology"); Martin Shapiro, Corruption, Freedom and Equality in Campaign Financing, 18 HofSTRA L. REV. 385, 393 (1989) (excessive political influence by the rich has been characterized as a "pathology" to be "excised").

${ }^{134}$ Brooks, supra note 21 , at $57,59$.

${ }^{135}$ Shihata, supra note 19, at 262. As a former Secretary-General of the Council of Europe stated: "“[n]one of our countries is immune from the disease of corruption. This disease is spreading in countries which regard or regarded themselves as old and firmly established democracies ... . The disease is spreading in the new democracies and those countries of Central and Eastern Europe where democracy is still being built." Peter Csonka, Corruption: The Council of Europe's Approach, in CORRUPTION: THE ENEMY WITHIN, supra note 19, at 343, 345 (quoting GMC (95) 9, Conclusions and Resolutions of the $19^{\text {th }}$ Conference of European Ministers of Justice, Valletta, Malta, June 14-15, 1994).
} 
Practices Act ${ }^{136}$ is described by another commentator as having been "partially motivated by an endemic, expressed American fear that the contagion of corruption, ... caught abroad, would emigrate to the United States, corrupting otherwise law-abiding domestic business." The Act "was conceived as a vigorous inoculation against this disease."137 Yet another commentator observes that once the contagion of corruption is embedded, the only solution is to "cut away the diseased tissue." 138

Indeed, references to the organic nature of corruption - as warping, corroding, perverting, or degrading the afflicted individual - can be found throughout the sociological and legal treatments of the subject. Corruption is described as a loss of purity and purpose, ${ }^{139}$ or the "decomposition of the body politic through moral decay." 140 As one commentator has observed, "the word corruption, used with reference to social phenomena, [is frequently juxtaposed] with such words as slime, filth, sewage, stench, tainted, rottenness, gangrene, [and] pollution ...." "Another states that "corruption and nepotism rot good intentions and retard progressive policies."142

Under all of these accounts corruption is powerful, and human beings are weak. Susceptibility to corruption is believed to be "within us all, like the potential for violence, deceit, and no doubt lust." ${ }^{143}$ The idea of corruption as involving an external evil, to which a human being

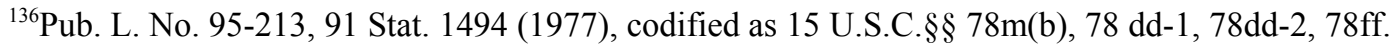

${ }^{137}$ Henry H. Rossbacher \& Tracy W. Young, The Foreign Corrupt Practices Act: An American Response to Corruption, in CORRUPTION: THE ENEMY Within, supra note 19, at 209, 224-25.

${ }^{138}$ Lippmann, supra note 25, at 296.

${ }^{139}$ See Arnold J. Heidenheimer, Introduction, in POLITICAL CORRUPTION: CONCEPTS \& CONTEXTS, supra note 13 , at 1, 6-7.

${ }^{140}$ FrIEDRICH, supra note 17, at 128. See also Euben, supra note 96, at 222.

${ }^{141}$ Brooks, supra note 21, at 57.

${ }^{142}$ K.T. Young, New Politics in New States, 39 Foreign AfFAIRS 498 (April, 1961).

${ }^{143}$ Rider, supra note 123 , at 1 . "[E]very person will at some point ... and at some level hear the seductive siren song of the corrupt temptress summoning us to, in Dante's words, enter ... the gates of Hell." Parker, supra note 95, at $102-03$. 
succumbs and which - in turn - destroys that person, leads us to the third and final proposition:

- $\quad$ Corruption does not describe an act, or a series of acts. It describes the capture of a human being by evil.

All of the traditional theories of corruption that we considered above - corruption as illegality, breach of duty, betrayal, secrecy, inequality, subversion of the public interest, and so on - assume that corruption is an act, or series of acts, that we identify (through the chosen theory). In fact, this assumption is fundamentally misconceived. What we mean by corruption cannot be captured by conduct, no matter how identified. It is - as our first two propositions suggest - far more. It is the capture of a human being by evil.

Consider, again, the following statements:

- A has broken the law

and:

- A is corrupt.

In discussing these statements above, we noted that they may have little congruence: an act can violate the law, but not be corrupt, and vice-versa. Now we can make a deeper and bolder assertion of difference. Corruption is different from simple law-breaking in the following, fundamental way. In the case of law-breaking, it is an act that we condemn. In the case of corruption, it is a person whom we condemn.

Corruption is, in short, a status. A person, when corrupt, has changed. Evil has captured her being, her essence, her soul.

The extent to which contemporary accounts use this model, and yet fail to recognize its usage, is stunning. All of the following examples were taken from academic or judicial writings that 
assume that corruption is an act that we condemn on legal, public-duty, public-interest, or other grounds. Yet, consider the following images of "capture":

- Individuals who commit corrupt acts are described by status: "corrupt insiders," "corrupt bidders," "corrupt officials," "corrupt leaders."144

- Corruption offenses are cumulatively described as "through-going corruption," "145 "corruption of character."146

- "Bribes corrupt people. Those who pay bribes are corrupted as well as those who receive them." 147

- A corrupt judge is described in the following terms: “[o]nce he embarked on the path of bribetaking, ... he had forsaken his judicial oath. ... His deviation from the path of righteousness ... was cold, calculated, and spanned a period of years ... ." His bribetaking was not "just another 'bias' or 'influence', something external to his personality, or at least some severable part of it." Rather, "the cancer of the judge's corruption ... invaded [his] decisionmaking." It "remove[d] him from the category of the 'average' man.".148

- The same judge is described by the United States Supreme Court as having lead "a life of corruption," in which he "corrupt[ed] justice." He was "shown to be thoroughly steeped in corruption through his public trial and conviction." ${ }^{149}$ In its sentencing recommendation, the Government stated that the judge "surpassed the category of corrupt jurist to chart a new territory of defilement." 150

- When engaged in public service, the official's "whole personality is claimed" - a demand that is thwarted by corruption. ${ }^{151}$

- " $[\mathrm{W}]$ hen the prospect or the receipt of campaign money influences the

\footnotetext{
${ }^{144}$ See Rose-AcKerman, supra note 7, at 36, 99, 101, 199.

${ }^{145}$ Brooks, supra note 21 , at 59 .

${ }^{146}$ ALATAS, supra note 30 , at 6 .

${ }^{147}$ Osborne, supra note 38, at 28 (emphasis added). See also GeORg SimMEL, The PhiLosophy OF MonEy 384 (trans. Tom Bottomore and David Frisby, 1978) (referring to bribery as "the purchase of a person").

${ }^{148}$ Bracy v. Gramley, 81 F.3d 684, 703 ( $7^{\text {th }}$ Cir. 1996) (Rovner, J., dissenting).

${ }^{149}$ Bracy v. Gramley, 520 U.S. 899, 906 (1997).

${ }^{150}$ United States ex rel. Collins v. Welborn, 79 F.Supp.2d 898 (N.D. Ill. 1999).

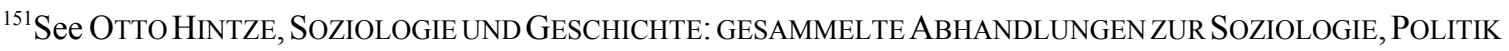
UND THEORIE DER GESCHICHTE 72 (1964). See also Heidenheimer, supra note 16, at 16. 
behavior of public officials, they are corrupted whether or not a deal has been made." $" 152$

- $\quad$ Removing a trial judge from office after he took a single bribe, a state supreme court declares that he "sold [his] ... power, he sold his judgments, he sold his independence." 153

Or, consider the following account of the prosecutor's closing argument in the corruption trial of an attorney and part-time judge:

During the trial, Tokars' attorneys presented their client as a pillar of the society, a respected attorney, a family man, and a political supporter of respected elected officials. The government argued that he was "a wolf in sheep's clothing." [He was a] [m] an who had carefully cultivated an outward appearance of goodness, but who underneath was evil and corrupt. Government counsel ... suggested to the jury that an analogy of Tokars' conduct may be found in the poetic masterpiece, the Inferno, [by] ... Dante Alighieri, one of the greatest poets of all time.

[In the Inferno,] [a]s the poets traveled through Hell's gates, ... they visited many levels. In the Sixth Bolgia they came upon the Hypocrites. ... Dante described the hypocrites' outward appearance as shining brightly, passing for holiness. But, underneath the gilded robes, each hypocrite carried the terrible weight of his deceit which his soul must bear throughout all eternity ... . It was suggested to the jury that, while Frederic Tokars' outward appearance was of goodness, underneath he carried the weight of deceit ....... Frederic W. Tokars lived a life of hypocrisy, a life of corruption. ${ }^{154}$

Such references to "corrupt officials," "corrupt leaders," "lives of corruption," judges "steeped in corruption," "corrupt hypocrites," and so on do not seem strange or as over-reaching to us. On a visceral level, they seem to be entirely appropriate characterizations of this evil. We are deeply convinced that corruption is not simply an act that may be forgiven, punished, or regretted,

\footnotetext{
${ }^{152}$ Burke, supra note 45 , at 653 (emphasis added).

${ }^{153}$ In the Matter of Peter J. Coruzzi, 472 A.2d 546, 549 (N.J. 1984).

${ }^{154}$ Parker, supra note 95 , at 102.
} 
or an attitude that may prevail in someone's mind one day and be gone the next. We believe it to be far more powerful. It is a "virus," a "contamination," an external, destroying force that must be "purged" if ever it is to be eradicated. ${ }^{155}$ It is the capture of a human being by evil. It is the purchase, by the devil, of one's soul.

Recognition of the influence of this idea of corruption explains why the traditional theories of corruption, described above, fail to capture the essence of this concept. The possible use of this idea in legal contexts is, however, an unsettling one. Long ago, we abandoned the idea of "corruption of the blood," under which those convicted of crimes and their offspring were believed to be irrevocably tainted and stripped of their legal rights. ${ }^{156}$ Corruption as capture-by-evil seems to be the retention of "corruption of the blood" in another guise. From a particular criminal act, it confers sweeping, irrevocable status on the actor as a moral outsider, consumed by evil, whom we should shun. Corruption as capture-by-evil might be an accurate expression of popular sentiments. But should it influence the administration of law?

\section{CORRuPTION AS CAPTURE-By-EviL: COSTS, BEnEFITS, AND CONSEQUENCES FOR THE RULE OF LAW}

The use in law of the idea of corruption as capture-by-evil is obviously fraught with problems. Status offenses contravene the idea that we punish acts, not persons. ${ }^{157}$ Invitation to decisionmakers to implement subjective ideas of evil is arguably standardless and violates the

\footnotetext{
${ }^{155}$ See Brooks, supra note 21, at 58 .
}

156، [W] hen any one is attainted of felony or treason, then his blood is said to be corrupt; by means whereof neither his children, nor any of his blood, can be heirs to him, or to any other ancestor, for that they ought to claim by him. And if he were noble or gentleman before, he and all his children are thereby made ignoble and ungentle ...." TERMES DE LA LEY $125\left(1^{\text {st }}\right.$ Am. ed. 1812).

${ }^{157}$ [e.g., Model Penal Code TK] 
principles of notice, fair procedure, and other safeguards that are a part of commitment to the rule of law. The legitimation of emotion as a part of criminal law is controversial at best and dangerous at worst. ${ }^{158}$ As Robert Brooks so well states, “[p]ublic anger at some exposed villainy of this sort is apt to be both blind and exacting." 159 This idea of corruption might capture the essence of the concept of corruption that traditional theories miss; but the costs of the use of this idea, in law, are high.

Are there any offsetting benefits that might justify these costs? In this Part, we will consider this question by exploring two settings in which the idea of corruption as capture-by-evil drives has great power: judicial corruption and campaign finance reform. I will argue that in these settings, the idea of corruption as capture-by-evil is, in fact, a superior conceptualization of vital interests at stake.

\section{A. The Corrupt Judge}

In April, 1993, former Cook County, Illinois Circuit Court Judge Thomas J. Maloney was convicted of racketeering, conspiracy to commit racketeering, extortion under color of official right, and obstruction of justice. ${ }^{160}$ Maloney was one of eighteen dishonest judges exposed and convicted through “Operation Greylord”, an intensive federal investigation of judicial corruption in Chicago. ${ }^{161}$

\footnotetext{
${ }^{158}$ Compare, for instance, Dan M. Kahan, What Do Alternative Sanctions Mean?, 63 U. CHI. L. REV. 591 (1996) and Dan Kahan, The Progressive Appropriation of Disgust, in THE PASsIONS OF LAW 63 (Susan A. Bandes, ed. 1999) (defending the expression of emotion in criminal law), with Sharon Lamb, The Psychology of Condemnation: Underlying Emotions and Their Symbolic Expression in Condemning and Shaming, 68 BROOK. L. REV. 929 (2003) (moral outrage easily becomes anger at individuals, not acts, transgressing the appropriate boundaries of criminal law and warping the expression of societal ideals).

${ }^{159}$ Brooks, supra note 21 , at 56.

${ }^{160}$ See United States v. Maloney, 71 F.3d 645 ( $7^{\text {th }}$ Cir. 1995).

${ }^{161}$ See id.; Bracy v. Gramley, 520 U.S. 899, 901 (1997).
} 
A jury determined that Maloney had accepted payments to acquit two murder defendants, and to convict a third murder defendant of voluntary manslaughter. Evidence at trial indicated that Maloney's corruption began years before, when he was a practicing lawyer and bribed judges to ensure that mob figures escaped prosecution or conviction. ${ }^{162}$ "[B]y the time Maloney ascended to the bench in 1977, he was well groomed in the art of judicial corruption, an art that he could practice at least until 1986, when he correctly perceived that he was under the watchful eye of the FBI ...."163 In 1981, an individual named William Bracy was tried, convicted, and sentenced to death in then-Judge Maloney's courtroom. ${ }^{164}$ Although Maloney was not bribed in Bracy's case, he accepted bribes in other cases during and around the time of Bracy's trial. ${ }^{165}$ After Maloney was subsequently convicted of corruption, Bracy sought habeas corpus relief on the ground that it must be presumed that Maloney's corruption "permeate[d] his judicial conduct" and denied Bracy a fair trial. $^{166}$

Thus, Bracy's case squarely presented the following question: whether a judge, having acted corruptly in one (or more) instances, should be presumed to have acted in corruptly in all. In an article headlined "Justices Weigh How to Deal with Taint of Corrupt Judge."167 The New York Times reported the following colloquy during the United States Supreme Court argument in the case:

"You're saying that once on the take, a judge can never be trusted to be

${ }^{162}$ Bracy v. Gramley, 81 F.3d 684, 696 ( $7^{\text {th }}$ Cir. 1996) (Rovner, J., dissenting).

${ }^{163} \mathrm{Id}$.

${ }^{164}$ Bracy, 520 U.S. at 900-01.

${ }^{165}$ Id. at 901 .

${ }^{166}$ Bracy, 520 U.S. at $901 ; 81$ F.3d at 689.

${ }^{167}$ Linda Greenhouse, Justices Weigh How to Deal with Taint of Corrupt Judge, N. Y. TIMES, April 15, 1997, at A9. 
unbiased," Justice Anthony M. Kennedy said to Gilbert H. Levy, [Bracy's lawyer] ... . Mr. Levy replied, "Someone with so little concern for his oath of office that he takes bribes to fix murder cases" should be presumed to have presided over a fundamentally corrupt courtroom. ${ }^{168}$

There are two theories in which such a broad, presumed conception of judicial corruption might be grounded. First, there is the idea that because Maloney favored the defense in cases that were "fixed," he had an incentive to favor the prosecution in other cases in order to "balance" the scales. This is the theory that Bracy advanced. ${ }^{169}$ This theory retains a transactional focus: from the existence of corruption in one transaction, we may (factually) presume the existence of corruption in another. In the alternative, there is the use of the theory of corruption as capture-by-evil. In this view, a judge such as Maloney, who has been proven to have acted corruptly in one (or more) instances, is deemed to be "captured by evil" such that all of his actions are presumed to be corrupt. In discussing Maloney, his corruption, and its general effects, both the Seventh Circuit and Supreme Court opinions are replete with images of a corrupt judge captured by evil. Judge Posner, writing for the Seventh Circuit's majority, agrees that the assumption that "a judge's corruption is likely to permeate his judicial conduct rather than be encapsulated in the particular cases in which he takes bribes ... is plausible ....".$^{170}$ He agrees that the judicial corruption of Maloney and his colleagues "has tainted the judicial system of Illinois, caused unjust acquittals, jeopardized convictions, tarnished the legal profession, and raised profound doubts ... about the entire political culture of the State."171 Justice Rehnquist, for the Supreme Court, describes how Maloney lived a

\footnotetext{
${ }^{168} \mathrm{Id}$.

${ }^{169}$ See Bracy, 520 U.S. at 902.

${ }^{170}$ Bracy, 81 F.3d at 689.

${ }^{171}$ Id. at 691.
} 
"life of corruption"; how he "corrupt[ed] justice"; how he was "shown to be thoroughly steeped in corruption through his public trial and conviction." 172

However, despite these sweeping characterizations of Maloney's corruption, both courts refused to see his corruption - as a remediable, legal matter - in other than transactional terms. The question, as framed by Posner, is whether there was actual harm - that is, whether Maloney was actually biased - in the handling of Bracy's case. A defendant in such a case "must show the actuality, rather than just the appearance" of judicial bias or prejudice in his case. "The fact that Maloney [may have] had an incentive to favor the prosecution in cases in which he was not bribed does not mean that he did favor the prosecution in such cases ... ."173 For Posner, the focus here is whether, in the Bracy-Maloney transaction, there was harm to Bracy's interests - something that was not, in his view, proven in the case. The Supreme Court's decision, although more charitable in theory was, in practice, not much more so. It held that Bracy had shown sufficient cause to be entitled to discovery, to see if he could prove that Maloney was actually biased in his case. "It may well be," Justice Rehnquist wrote, "as the Court of Appeals predicted, that [Bracy] ... will be unable to obtain [such] evidence ... ." However, he was entitled to try. ${ }^{174}$

${ }^{172}$ Bracy, 520 U.S. at $906,909$.

${ }^{173}$ Bracy, 81 F.3d at 689.

${ }^{174}$ Bracy, 520 U.S. at 908-09. On remand, the Federal District Court held that the evidence clearly substantiated Maloney's corruption. It also held that it was "possible and reasonable to infer" that Maloney made pro-prosecution rulings to deflect attention from the cases in which he was bribed. This "inference of improper motivation" was not enough, however, to vacate the jury's verdicts of guilt. "Maloney's bribetaking [was] ... not shown to have been so pervasive a part of his judicial practices that it can be assumed that he was always, or even usually motivated by his [own] ... interests when exhibiting his prosecution-oriented tendencies." As a result, there was "no substantial reason to think that ... the jury's findings were tainted by Maloney's collateral corruption." However, a new sentencing hearing was ordered. Welborn, 79 F.Supp.8989, at 908-911. On appeal, this result was ultimately affirmed. Bracy v. Schomig, 286 F.3d 406 ( $7^{\text {th }}$ Cir. 2002) (en banc).

The District Court's implicit distinction between a jury's findings [of guilt] and a judge's finding [of sentence] in this context is curious. As the Seventh Circuit observed in a similar case, "it is irrelevant that [the defendant] ... was convicted by a jury, for the judge's role in presiding over a jury trial is obviously not of a merely ministerial character ..., in which no opportunity to act on bias could arise." Cartalino v. Washington, 122 F.3d 8, 10 (1997). 
The outcome in both courts was undoubtedly influenced by the stark judicial choice that the case presented. If Bracy was entitled to relief, so were thousands of others whose cases had been tried in the corrupt judge's court. Posner notes, in his opinion, that "[a] principled acceptance of ... [Bracy's] argument would require the invalidating of tens of thousands of civil and criminal judgments, since Judge Maloney alone presided over some 6,000 cases during the course of his judicial career and he is only one of eighteen Illinois judges who have been convicted of accepting bribes." 175 The outcome is, however, viscerally unsatisfactory on its own terms. How can a defendant prove, in such a case, that the judge's actions or attitudes were altered? As Judge Rovner noted in dissent, "except in rare cases in which the judge's agenda is obvious, we cannot expect to autopsy a trial and find evidence that the cancer of the judge's corruption has invaded her decisionmaking." 176 Indeed, it is precisely because of such problems in proof of prejudice that convictions rendered in cases in which bribes are taken are presumed to be corrupt. ${ }^{177}$

The nearly insuperable difficulties in proving actual bias on the part of an otherwise corrupt judge are aptly illustrated by United States ex rel. Guest v. Pope. ${ }^{178}$ Guest was convicted of murder and sentenced to death. ${ }^{179}$ The presiding judge was Cook County, Illinois Circuit Judge Maurice Pompey. Evidence uncovered during the "Operation Greylord" investigation, and by Guest's postconviction attorneys, established the wide-spread scope of Pompey's corruption. Numerous witnesses interviewed by the F.B.I. claimed that Pompey routinely accepted cash bribes in exchange

${ }^{175}$ Bracy, 81 F.3d at 689.

${ }^{176}$ Bracy, 81 F.3d at 703 (Rovner, J., dissenting).

${ }^{177}$ See, e.g., Bracy, 520 U.S. at 904-05; Vasquez v. Hillary, 474 U.S. 254, 263 (1986). A verdict rendered by a bribed judge violates the defendant's constitutional right to a fair trial, no matter how powerful the case against the defendant or how fair the judge's rulings may have appeared to have been. Cartalino, 122 F.3d at 9-10.

${ }^{178} 2004$ U.S. Dist. Lexis 4678.

${ }^{179}$ Id. at 2. Guest's sentence was later commuted by the Governor to life in prison without parole. Id. 
for favorable dispositions in serious criminal cases. Lucius Robinson, who was Judge Pompey's personal bailiff, claimed that he passed bribes to the judge on hundreds of occasions. The files of the U.S. Attorney indicated that certain corrupt defense attorneys would routinely request that their cases be assigned to Pompey. An F.B.I. agent testified that he gave money to Robinson to influence Pompey in a case that occurred around the time of Guest's trial. ${ }^{180}$ However, despite this evidence and more, the Court reached the "difficult conclusion" that Guest's challenge could not succeed. “Although counsel's commendable efforts have revealed much disturbing evidence, the Court must conclude that Guest has not satisfied the heavy burden of proving ... Pompey's actual bias."181 Guest did not prove that Pompey "engaged in compensatory bias [i.e., overly harsh treatment of nonbribing defendants] in his case." 182

The appellate courts' use of a transactional approach which requires proof of prejudice in Bracy's case is also deeply unsatisfactory on other grounds. If a judge is "corrupt," and his court is "corrupt," how can a fair trial have been conducted, and justice done, in that judge's court? As Judge Rovner argued, "[w]hat are we to say to Bracy ..., that [he] had the right to an honest, impartial judge but that the breadth of past corruption in the Illinois judiciary makes it too costly for us to enforce that right? [Is he] ... to become the latest victim[] of Maloney's bribetaking, and we his accomplices ...?"183 It is the universal rule that if a judge is indicted for accepting bribes, he will be immediately removed from active service; if he is convicted - for even one bribe - he will be

\footnotetext{
${ }^{180}$ Id. at $15-20$.
}

${ }^{181}$ Id. at 19.

${ }^{182}$ Id. at 22-23 (emphasis in original). To a similar effect, see United States v. Lucas, 89 F.Supp. 2 d 976 (N.D. Ill. 1999). Cf. Cartalino, 122 F.3d at 10-11 (evidence that a codefendant, tried at the same time and by the same judge, bribed the judge for lenient treatment "does not in and of itself establish the judge's lack of impartiality in the [nonbribing] defendant's trial"; however, the case was remanded for the development of further evidence that part of the deal was that the defendant would "take the fall").

${ }^{183}$ Bracy, 81 F.3d at 703 (Rovner, J., dissenting). 
permanently removed from office. ${ }^{184}$ It is highly ironic to argue in Bracy's case that his conviction should remain in tact when, had Maloney's corruption been known at the time of Bracy's trial, Maloney would never have been permitted to have heard the case.

This brings us to the final and most fatal flaw in the transactional model: its failure to capture the systemic costs and systemic dangers that judicial corruption presents. It is not the act of the corrupt judge (as reprehensible as it may be) that causes our true alarm; it is what that act says about our ability to believe in the system of law and in the system of justice. A judge is not simply a public servant; he is a "carefully protected eminence," "the trustee of the assurance of justice."185 "The solemnity of legal procedure and the perpetuation of traditional forms - such as the judicial robes, the bailiff's incantations ..., the ceremonial architecture of the courts themselves - all bespeak of the [judge's] exalted station ...."186 A dishonest judge jeopardizes not only himself, and the litigants before him, but also the integrity of the entire judicial process. Systemic costs and systemic dangers are presented by all aspects of that judge's tenure. As Judge Evans wrote for the Seventh Circuit's en banc majority, “[n]ot only is [Maloney] not entitled to any presumption of fairness, ... he is entitled to our derision. ... [H]e was a criminal who, by his very presence on the bench, undermined the foundation of our system of justice. ... [H]e was a racketeer sending men to the death chamber in the name of the State." 187 Compounding this truth is the additional unseemliness involved in judicial (or societal) affirmation of a corrupt judge's actions. If we embrace judgments rendered by corrupt judges, we embrace their stain and "the judicial service of

\footnotetext{
${ }^{184}$ See e.g., In the Matter of Peter J. Coruzzi, 472 A.2d 546, 550 (N.J. 1984) (“[A] judge who accepts a bribe must be removed from office. There can be no exceptions whatsoever.").

${ }^{185}$ BORKIN, supra note 128 , at $10,9$.

${ }^{186}$ Id. at 10.

${ }^{187}$ Bracy, 286 F.3d at 411. This majority still felt bound to honor the "actual bias" test in Bracy’s case. Id.
} 
outlaws" that produced them. ${ }^{188}$

Indeed, it is because of these obvious systemic costs that the idea that the existence of judicial corruption is "outcome-dependent" - that is, that it exists only if prejudice is shown - has been rejected, as a general proposition, for centuries. Famous defendants have asserted this defense and been rebuffed. For instance, Sir Francis Bacon, English Lord Chancellor, asserted that his bribetaking never influenced his decisions, and that sometimes he decided against the parties who paid the bribes. He conceded, however, that even if he were the "justest chancellor," he was deserving of "the justest censure,", a judgment in which Parliament obliged. ${ }^{189}$ Martin T. Manton, a notoriously corrupt federal judge, argued on appeal that his corruption convictions could not stand because the cases in which he had been paid were (in fact) correctly decided. This argument was rejected. The reviewing court pointed out that the crime was not his rulings; it was the agreement to take money in exchange for the exercise of judicial power. ${ }^{190}$

It is this systemic danger and systemic damage that a transactional theory of judicial corruption fails to capture, and that the idea of corruption as capture-by-evil identifies. The idea of capture-by-evil imagines corruption as an external force, that (perhaps uniquely) transcends individual acts. If, for instance, a judge is found to be a murderer, we are shaken by the revelation, but we do not fear that other judges will be encouraged to yield to their weaknesses or that, as a result of this revelation, the idea of the rule of law will be broadly undermined. Corruption is different. When figures as revered as judges are revealed to be corrupt, problems of widespread

\footnotetext{
${ }^{188}$ Bracy, 81 F.3d at 704 (Rover, J., dissenting).

${ }^{189}$ See BORKIN, supra note 128 , at 5 .

${ }^{190}$ See NoONAN, supra note 91, at 569; United States v. Manton, 107 F.2d 834, 846 (2 $2^{\text {nd }}$ Cir. 1939).
} 
decadence are suggested to the public. ${ }^{191}$ The existence of corruption impairs social and political stability, and general faith in the rule of law. Judicial corruption is a "cancer" or "virus" or "disease" because of the broad dangers that it presents to the rule of law and to the maintenance of government institutions.

Thus, our choices are difficult. If we allow corruption as capture-by-evil to influence the identification, prosecution, and punishment of judicial corruption, we may well run afoul of the rule of law and its requirements of standards, proof, and transaction-oriented (rather than status) offenses. If, however, we refuse to acknowledge the broader concerns that this idea of corruption captures, we ignore, at our peril, the clear systemic costs and dangers that corruption presents.

\section{B. Campaign Finance Reform}

The Federal Election Campaign Act, enacted in 1971 and extensively amended in 1974, ${ }^{192}$ was the first comprehensive attempt by Congress to regulate the financing of congressional and presidential campaigns. ${ }^{193}$ Its primary thrust was to implement campaign finance reform through the regulation of political campaign contributions and expenditures. It also provided a system for public funding of Presidential campaign activities, and established the Federal Election Commission to administer and enforce the legislation.

Less than two years after its enactment, the Supreme Considered the constitutionality of the

191، A bribed judge not only sacrifices his own morality but poisons the well of justice itself ...”. BORKIN, supra note 128, at 17. Early English law regarded bribery of a judge as among the most heinous of crimes, and punished it as high treason. Id. See also Bayley, supra note 15, at 527 and Gunnar Myrdal, Corruption as a Hindrance to Modernization in South Asia, in POLITICAL CORRUPTION: READINGS IN COMPARATIVE ANALYSIS, supra note 15, at 23132 (discussing the distortionate, damaging, and contagious effects of the corruption of top public officials).

${ }^{192}$ Federal Election Campaign Act of 1971 (FECA), Pub. L. No. 92-225, 86 Stat. 3 (1972) (codified as amended at 2 U.S.C. $\S \S 431-55$ and 18 U.S.C. $\S \S 591-610$ (2000)).

${ }^{193}$ For a history of prior legislation, see FRANK J. SORAUF, INSIDE CAMPAIGN FINANCE 1-8 (1992). 
Act in the watershed case of Buckley v. Valeo. ${ }^{194}$ The results were mixed. All expenditure limits, except those by political parties, were struck down on First Amendment grounds. ${ }^{195}$ On the other hand, contribution limits, disclosure requirements, record keeping requirements, and public financing provisions were upheld. ${ }^{196}$ In upholding these provisions, the Court established the prevention of the "actuality and appearance of corruption"197 as the critical government interest in this field.

What the Buckley majority believed the "actuality and appearance of corruption" to involve is the subject of some elaboration in the opinion. First, the Court cited actual quid-pro-quo arrangements: "[t]o the extent that large contributions are given to secure a political quid pro quo from current and potential officeholders, the integrity of our system of representative government is undermined." ${ }^{\prime 198}$ Although the incidence of such arrangements was difficult to know, "the deeply disturbing examples surfacing after the 1972 election demonstrate that the problem is not an illusory one."199 In addition, and "[o]f almost equal concern, was "the impact of the appearance of corruption stemming from public awareness of the opportunities for abuse inherent in a regime of large individual financial contributions." ${ }^{200}$ Quoting an earlier case, the Court stated that "Congress could legitimately conclude that the avoidance of the appearance of improper influence 'is also critical ... if confidence in the system of representative Government is not to be eroded ... ."201

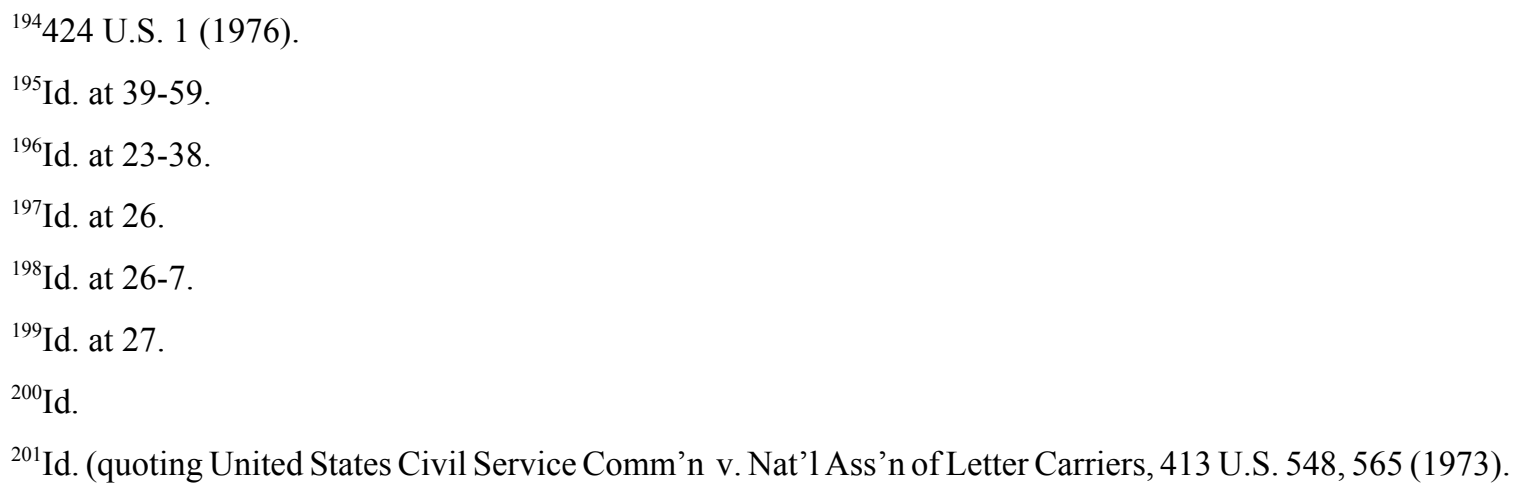


Thus, that the "actuality and appearance of corruption" encompassed more than the criminal giving and taking of bribes was clear. ${ }^{202}$ However, a vast range of conduct and potential governmental interests stretched beyond this point. Did the "appearance of corruption," for instance, target only those situations where there was a danger of quid-pro-quo arrangements? Or did this include broader concerns about influence and the power of money in political campaigns?

Through the next two decades, the Court followed a generally expansive path in the understanding of corruption and public interests in this context. For instance, in Austin v. Michigan Chamber of Commerce, ${ }^{203}$ the Court upheld state limitations on "independent" corporate campaign expenditures (i.e., those not controlled by or coordinated with a candidate) on the ground that "corporate dominance" of the political process would introduce a "different type of corruption ...: the corrosive and distorting effects of immense aggregations of wealth that are accumulated with the help of the corporate form. ${ }^{" 204}$ In Federal Election Commission v. Colorado Republican Federal Campaign Committee, ${ }^{205}$ the Court upheld limits on spending by political parties when that spending was coordinated with a candidate's campaign. Although the idea of quid-pro-quo relationships between parties and their own candidates is illogical, the Court reasoned that political parties could be used by donors to circumvent contribution limits and as conduits for contributions that were intended to foster a sense of obligation. Abuses of both kinds, the Court reasoned, would "exacerbate the threat of corruption and apparent corruption" that contribution limits were intended to prevent. ${ }^{206}$

\footnotetext{
${ }^{202} \mathrm{See}$ id. at $27-28$.

${ }^{203} 494$ U.S. 652 (1990).

${ }^{204}$ Id. at 659,660 .

${ }^{205} 533$ U.S. 431 (2001).

${ }^{206}$ Id. at 453 .
} 
In McConnell v. Federal Election Commission ${ }^{207}$ the Court's latest and most comprehensive opinion on the subject, this trend toward broad understandings of corruption and legitimate government interests in the campaign-finance context continued. At issue in McConnell was the Bipartisan Campaign Reform Act of 2002, ${ }^{208}$ which targeted the "soft money loophole" - money as yet unregulated by the FECA - and issue advertising intended to influence federal elections. In upholding the BCRA's central provisions, the Court emphasized the dangers presented by "great aggregations of wealth"209 and by "big money campaign contributions."210 Corruption caused by money in politics, in the Court's view, takes several forms. First, there is the danger of cash-forvotes, or express or implied quid-pro-quo agreements. ${ }^{211}$ In addition, there is the problem of "politicians too compliant with the wishes of large contributors" - in other words, the general problem of obligation or undue influence on an officeholder's judgment. ${ }^{212}$ Finally, there is the more diffuse but important danger that public confidence in the electoral process will be eroded. If common citizens believe (rightly or wrongly) that government policies are simply bought and sold, individuals will feel no responsibility for the successful functioning of government. ${ }^{213}$

Thus, from these cases, the following understanding of corruption in campaign finance can be distilled:

${ }^{207} 540$ U.S. 93 (2003).

${ }^{208}$ Bipartisan Campaign Reform Act of 2002 (BCRA), Pub. L. No. 107-155, 116 Stat. 81 (codified in scattered sections of 2, 18, 28, 36, 47 U.S.C.).

${ }^{209}$ McConnell, 540 U.S. at 115 (internal quotation marks omitted).

${ }^{210}$ Id. (internal quotation marks omitted).

${ }^{211}$ Id. at 143 .

${ }^{212}$ Id. (internal quotation marks omitted).

${ }^{213}$ Id. at 143-44. See also Nixon v. Shrink Mo. Gov't PAC, 528 U.S. 377, 390 (2000) (the perception that "large donors call the tune" might "jeopardize the willingness of voters to take part in democratic governance"). 
- $\quad$ Corruption includes proof of actual quid pro quo agreements, and situations with a demonstrable danger of quid pro quo arrangements, between contributors and candidates.

- Corruption involves situations that fall short of a quid pro quo, but that nonetheless foster a sense of obligation on the part of officeholders to contributors, or otherwise involve undue influence.

- Corruption involves the distortion of the political process through concentrated wealth, e.g., through the spending of corporate money in political campaigns.

- $\quad$ Corruption includes the impression of control of the political process by big donors, with resultant cynicism and alienation of the populace.

With the exception of corruption of the first type, all of these understandings go far beyond the transactional or quid-pro-quo model of corruption in politics. We are not concerned, here, with simply the existence of quid-pro-quo arrangements, or even the danger of quid-pro-quo arrangements; we are concerned with far broader political and popular influences, appearances, and effects that money in politics engenders.

Buckley and its progeny have been criticized on many grounds. ${ }^{214}$ Of particular interest to us are those criticisms that focus on the idea of corruption that these cases employ. ${ }^{215}$ For instance, in a very recent and interesting article, Nathaniel Persily and Kelli Lammie criticize the Supreme

\footnotetext{
${ }^{214}$ See, e.g., Kathleen M. Sullivan, Political Money and Freedom of Speech, 30 U.C. DAVIS L. REV.663, 687 (1997) (arguing that limits on campaign contributions "are in deeper tension with current First Amendment conceptions than is often supposed"); Vincent Blasi, Free Speech and the Widening Gyre of Fund-raising: Why Campaign Spending Limits May Not violate the First Amendment After All, 94 ColuM. L. REV.1281, 1283 (1994) (arguing that Buckley's upholding of contribution limits, and invalidation of spending limits, forces candidates to spend an inordinate amount of time on fundraising, which undermines representative government); Samuel Issacharoff \& Pamela S. Karlan, The Hydraulics of Campaign Finance Reform, 77 TEX. L. REV. 1705, 1714 (1999) (arguing that reforms will have the perverse effect of channeling money away from potentially mediating institutional buffers, such as candidates and political parties, and into the coffers of more extreme issue advocacy groups); SORAUF, supra note 193(arguing that fears about the influence of money in politics is greatly exaggerated); Bradley A. Smith, Faulty Assumptions and Undemocratic Consequences of Campaign Finance Reform, 105 YALE L. J. 1049, 1072-75 (1996) (limitations on campaign contributions reinforce the status quo by hindering the ability of challengers to compete with incumbents on equal terms).

${ }^{215}$ Some analysts have heartily embraced campaign corruption as capture-by-evil with capture images of their own. See, e.g., Amitai Etzioni, Capital Corruption: The New Attack on American Democracy xi (1988) ("Washington is corrupt to the core.").
} 
Court's failure to insist on a showing of "actual corruption," or that "campaign contributions have actually influenced" a legislator's conduct. ${ }^{216}$ They are incredulous that "the mere appearance of a problem" is cited, in these cases, to justify infringement of First Amendment values. ${ }^{217}$ In no other area of First Amendment jurisprudence are compelling state interests leaning upon such a slender reed. ${ }^{218}$ In fact, they speculate, "the Court's invocation of this novel state interest has less to do with the importance of removing unsavory appearances and more to do with the difficulty of proving actual corruption." 219 In their view, reliance on more intangible interests is simply a "fallback ... interest in the likely event that one cannot make the difficult showing" of actual influence on a legislator's conduct. ${ }^{220}$ This fallback interest is, in fact, "conjectural" at best and "irrational" or "vacuous" at worst. ${ }^{221}$

Whether the prevention of corruption (as conceived by the Court) is ultimately worth the First Amendment candle is beyond the scope of our inquiry. However, a vital part of that question is whether corruption, as conceived by the Court, has any real practical or intellectual legitimacy. To put it bluntly: does the idea of corruption, as expressed by the Court, serve any distinctly identifiable government interest in the campaign finance context? Or is it simply a poor substitute

${ }^{216}$ Nathaniel Persily and Kelli Lammie, Perceptions of Corruption and Campaign Finance: When Public Opinion Determines Constitutonal Law, 153 U. PENN. L. REV. 119, 121 (2004).

${ }^{217}$ Id. at 120.

${ }^{218}$ See id. at 124 (" $[\mathrm{T}]$ he state has compelling interest only in addressing problems that are both real and significant.").

${ }^{219}$ Id. at 121.

${ }^{220} \mathrm{Id}$.

${ }^{221}$ Id. at 124,129 . For similar criticisms, see, e.g., Smith, supra note 214 , at 1067 n. 113 (" $[$ T] $]$ he 'appearance of corruption' rationale is both unnecessary and dangerous. If the campaign finance system leads to actual corruption, then that may be a constitutionally sufficient justification for the state to infringe on free speech rights, in which case the 'appearance of corruption' is superfluous. If the campaign system does not lead to actual corruption, then it seems very dangerous to suggest that the mistaken view of some could justify restricting the First Amendment liberties of others."); D. Bruce LaPierre, Campaign Contribution Limits: Pandering to Public Fears About "Big Money" and Protecting Incumbents, 52 ADMIN. L. REV. 687, 688-90, 713-14 (2000) (the "appearance of corruption" is a "speculative," "amorphous," and "dangerous" standard for regulating political speech). 
for "actual," quid-pro-quo corruption?

The understanding of corruption that the Court employs (and that critics attack) is, in fact, an incarnation of the idea of corruption as capture-by-evil. In the Court's view, in the campaign finance context we are concerned with the existence of an external, explicit, "moral" bad (the influence of money), which may distort the political process, and to whose temptations candidates and officeholders may succumb. This is a species of capture-by-evil, on both an individual and systemic basis. Indeed, when discussing the dangers presented by money in politics, the Court has explicitly relied on images and ideas of this conception of corruption. For instance, corruption - in the form of large campaign contributions - is a "pernicious influence" that "insinuate[s] itself" into the political process. ${ }^{222}$ It is "corrosive and distorting.,"223 It is a "constantly growing evil" which has shaken the confidence of the people in government. ${ }^{224}$ It needs to be "purge[d]" from national politics. ${ }^{225}$

The key to the critics' position is this: that corruption consists of campaign contributions that have actually influenced a legislator's conduct. ${ }^{226}$ If we posit that "actual" corruption is the existence of successful quid-pro-quo transactions, then the conclusion that anything "less" than this

${ }^{222}$ McConnell, 540 U.S. at 117, 164.

${ }^{223}$ Austin v. Mich. Chamber of Commerce, 494 U.S. 652, 659-60 (1990).

${ }^{224} \mathrm{McC}$ Connell, 540 U.S. at 115. See also id. at 116 (money in politics is "one of the great political evils of [our] time") (internal quotation marks omitted)

${ }^{225} \mathrm{Id}$. at 115. See also id. at 354 (Rehnquist, J., dissenting in part) (discussing whether federal candidates or officeholders "are corrupted or would appear corrupted" by contributions); Nat'l Bank of Boston v. Bellotti, 435 U.S. 765,788 n. 26 (1978) (discussing the "corruption of elected representatives" through the creation of political debts); Buckley, 424 U.S. at 259 (White, J., concurring in part and dissenting in part) (discussing corruption's "mortal danger", against which effective steps must be taken). Work by academic commentators in this field utilize these images as well. See, e.g., DenNis F. ThOMPSON, ETHICS In CONGRESS: From InDIVIDUAL to INSTITUTIONAL CORRUPTION 28 (1995) (private interests that attempt to achieve political influence through campaign contributions are "agents of corruption"); Issacharoff \& Karlan, supra note 214, at 1734 (reforms in the campaign finance area should be aimed at "the worst pathologies").

${ }^{226}$ See, e.g., Persily \& Lammie, supra note 216 , at $135-36$. In their requirement that "campaign finance contributions affect policy outcomes," id. at 135, Persily and Lammie in fact go beyond the general requirements for quid-pro-quo corruption, which do not require proof of a different outcome. See text at notes 189-190, supra. 
is simply a poor substitute inexorably follows. However, this does not answer the primary question, which is this: are there broader government interests - perhaps even more critical government interests - that corruption as capture-by-evil, in this context, identifies?

In fact, we are concerned, in this area, not only with particular acts or particular votes, but with broad, institutional dangers. To put it simply, the existence and effects of corruption in the world of politics and campaign finance are far larger than quid-pro-quo transactions. We cannot, by focusing on the presence or absence of specific bribes, capture the broader institutional concerns of public trust in government. We are concerned not only with the possible quid-pro-quo transaction, but also with the cynicism and lack of trust in government - the suspicion that public policies and public offices are "bought and sold"227 - that free-wheeling spending by powerful interests in the campaign arena creates.

Indeed, of all government interests in this context, the maintenance of popular belief in the legitimacy of the political system is by far the most critical. Studies have overwhelmingly found that examples of quid-pro-quo corruption and (more importantly for our purposes) the perception of a culture of quid-pro-quo corruption destroy government legitimacy. For many years, political scientists have reported the effects of clientelism and cronyism on popular belief in government. ${ }^{228}$ It is also well known that "clientelism and related corruption (in the form of vote-buying and bribery) ... increas[e] trust between patron and client, and decreas[e] trust for the political system, which is viewed as being at the service of the highest bidder." 229 More recently, focus has shifted

${ }^{227}$ Buckley, 242 U.S. at 265 (White, J., concurring in part and dissenting in part).

${ }^{228}$ See, e.g., EdWARd BANFIELD, The Moral Basis OF A BACKWARd Society (1958); EVA ETZIONO-HALVEy, BUREAUCRACY AND DEMOCRACY (1985); Michal Johnston, Patrons and Clients, Jobs and Machines, 73 AMERICAN POL. SCI. REV. 385 (1979).

${ }^{229}$ Mitchell A. Seligson, The Impact of Corruption on Regime Legitimacy: A Comparative Study of Four Latin American Countries, 64 J. OF POLITICs 408, 412 (2002). 
to the effects of popular belief in the existence of corruption on belief in government legitimacy. The findings of these studies, which have included analyses of France, Chile, Germany, Italy, Mexico, Nicaragua, El Salvador, Costa Rica, Bolivia, Paraguay, Japan, and the United States, confirm what, perhaps, was obvious: that instances of quid-pro-quo corruption, and public belief in the existence of and opportunity for quid-pro-quo corruption, erode the legitimacy of government. ${ }^{230}$ What critics of the Supreme Court's conception of campaign-finance corruption miss is that corrupt transactions are only a small part of the larger problem of corrupt institutional capture. Transactional crimes may be the most familiar and obvious example of perversion of the political process; however, their true importance and true danger lie in the larger message that they signal. The larger concern, of which they are a part, is the maintenance of faith in government. Toward that end, government must be empowered - First Amendment concerns aside - to implement prophylactic measures. ${ }^{231}$

There are obvious problems with the idea of corruption as capture-by-evil in this context, and in the prophylactic measures that it encourages. For instance, all contributions (and acts) by constituents have the potential to influence candidates and officeholders, suggesting (under this theory of corruption) no obvious limiting principle. In addition, the view of favoritism and influence as "evil" may (under particular theories of representative government) itself be flawed, in the belief

\footnotetext{
${ }^{230}$ See Donatella della Porta, Social Capital, Beliefs in Government, and Political Corruption, in DISAFFECTED Democracies: What's Troubling THE Trilateral Countries? 202 (Susan J. Pharr \& Robert D. Putnam eds., 2000); StePHEN D. Morris, CORRUPTION AND Politics In CONTEMPORARY MEXICO 102-14 (1991); Susan J. Pharr, Officials' Misconduct and Public Distrust: Japan and the Trilateral Democracies, in DisAFFECTED DeMOCRACIES: WhAT'S Troubling the Trilateral Countries, supra, at [TK] ; Seligson, supra note 229; BENJAMIN I. PAGE \& RoberT Y. Shapiro, The Rational Public: Fifty Years of Trends in AMERicAns' Public Policy PreferenCes 337-38 (1992). Typical is the conclusion of Morris: "Pervasive corruption produces a pernicious 'culture of corruption' among the public that includes widespread distrust and cynicism toward public officials. ... [T] his distrust greatly magnifies the potential loss of legitimacy that [necessary to] sustain the state's organizations." Morris, supra, at 18.

${ }^{231}$ Indeed, a prophylactic approach to the corruption of public officials is routine in other settings. See, e.g., 5 U.S.C. $\$ 7353(a)(2)$ (prohibiting gratuities to employees of the executive, legislative, and judicial branches); 18 U.S.C. $\S 209$ (a) (prohibiting the "supplementation" of an executive branch official's salary); 18 U.S.C. §§ 212-213 (prohibiting any loan or gratuity by a bank employee to a bank examiner).
} 
that such are legitimate, or impossible to prevent, or - at the least - the ordinary grist of politics. However, no matter how we weigh these concerns, the truth remains: that corruption, in this sense, is not simply a stand-in for unprovable transactional crimes. It is its own evil, its own force, its own

identification of systemic corrosion. Rather than being seen as "[c]atering to irrational fears," 232 campaign finance reform that recognizes the idea of capture-by-evil might well be seen as an attempt to address this critical interest of government.

\section{CONCLUSION}

Efforts by political scientists, economists, legal academics, and others to articulate a "politically neutral, methodologically respectable, operational viable definition"233 of public corruption have had little success. Shell theories, such as corruption-as-illegality or corruption-asbreach-of-duty, are both radically over- and under-inclusive, and have little true substantive content. Often, corrupt acts will fall into these categories, but it is not the illegality or breach of duty that identifies the corrupt nature of the action. Substantive theories - citing betrayal, secrecy, inequality, subversion of the public interest, and economic concerns - go farther, by identifying elements that are often important characteristics (or consequences) or corrupt acts. However, again, these theories fail to identify the essence of corruption. These characteristics are not, alone or in combination, what comprises the corrupt core.

The idea of corruption that animates public contexts is, instead, a far deeper and more complex idea: it is an explicitly moral notion, invoking notions of "depravity" and "evil", human

\footnotetext{
${ }^{232}$ See Persily \& Lammie, supra note 216 , at 124.

${ }^{233}$ Euben supra note 96, at 222.
} 
frailty and temptation. It is imagined as an external force, which attacks and undermines better human impulses. It is not simply an act, or a series of acts. It is the capture of individuals (and political systems) by corrosive, distorting, and decomposing forces. It is self-involvement, selfindulgence, the loosening and discard of the restraint of social bonds.

Recognition of the idea of corruption as capture-by-evil in the design and enforcement of law carries many obvious dangers. "Capture" and "evil" are hardly justiciable concepts, with known or accepted meanings. Corruption as "capture-by-evil is not descriptive of "acts," but rather of "status" - thus violating one of the most sacred tenets of criminal law. To paraphrase what I have written in another context, we see the corrupt individual "not as a person who has done evil, but as someone who is possessed by evil." We "break the tie of kinship." We "create a chasm between him and ourselves. ${ }^{234}$

We could, perhaps, try to minimize these problems by using this conception of corruption in those contexts where its usefulness is most apparent and its dangers least. For instance, in the judicial context we could allow its use - overtly or covertly - in cases of judicial removal or the treatment of previously rendered judgments, and prohibit its use in criminal prosecutions or punishments for what are (in fact) individual acts. However, the power of this idea with its deep, intuitive roots will be difficult to contain. It is hard to imagine that if we are free to demonize a judge as "thoroughly steeped in corruption" or "completely decadent to the core" for the purposes of considering the validity of her judgments, we will not consider that depravity when punishing her for that crime.

The costs of the idea of corruption as capture-by-evil, for the rule of law, are real. However,

\footnotetext{
${ }^{234}$ Laura S. Underkuffler, Agentic and Conscientic Decisions in Law: Death and Other Cases, 74 NOTRE DAME L. REV. 1713, 1734 (1999).
} 
to insist upon an understanding of corruption in transactional terms has costs for the rule of law as well. The idea of corruption as capture-by-evil is not simply an idea of extreme moralists, or popular sentiment run amok; it is a recognition of the deep, systemic dangers that actual quid-proquo corruption, the presence - in office - of judges (or others) who have engaged in quid-pro-quo corruption, and the opportunity for quid-pro-quo corruption present for the very idea of the rule of law and its ability to control conduct. Corruption involves the discard of collective restraints, and the perversion of the apparatus of government. As Peter Euben has observed, "corruption is a disease of the body politic. It has less to do with individual malfeasance than with systematic and systemic degeneration of those practices and commitments that provide the terms of collective selfunderstanding and shared purpose. ${ }^{, 235}$ It is that concern that the idea of corruption as capture-byevil, however imperfectly, attempts to express.

${ }^{235}$ Euben, supra note 96 , at 222. 